\title{
Viability Assessment in Liver Transplantation-What Is the Impact of Dynamic Organ Preservation?
}

\author{
Rebecca Panconesi ${ }^{1}$, Mauricio Flores Carvalho ${ }^{1}$, Matteo Mueller ${ }^{2}$, David Meierhofer ${ }^{3}{ }^{\circledR}$, Philipp Dutkowski ${ }^{2}$, \\ Paolo Muiesan ${ }^{1}(\mathbb{D}$ and Andrea Schlegel 1,2,*(D) \\ 1 Hepatobiliary Unit, Careggi University Hospital, University of Florence, 50134 Florence, Italy; \\ rebeccapanconesi@gmail.com (R.P.); drmauras@gmail.com (M.F.C.); paolo.muiesan@unifi.it (P.M.) \\ 2 Department of Visceral Surgery and Transplantation, University Hospital Zurich, \\ Swiss HPB and Transplant Center, 8091 Zurich, Switzerland; matteo-mueller@usz.ch (M.M.); \\ philipp.dukowski@usz.ch (P.D.) \\ 3 Max Planck Institute for Molecular Genetics, Mass Spectrometry Facility, 14195 Berlin, Germany; \\ Meierhofer@molgen.mpg.de \\ * Correspondence: schlegel.andrea@outlook.de
}

Citation: Panconesi, R.; Flores Carvalho, M.; Mueller, M.; Meierhofer, D.; Dutkowski, P.; Muiesan, P.; Schlegel, A. Viability Assessment in Liver Transplantation-What Is the Impact of Dynamic Organ Preservation? Biomedicines 2021, 9, 161. https://doi.org/10.3390/ biomedicines 9020161

Academic Editor: Giovanni Squadrito Received: 18 January 2021

Accepted: 3 February 2021

Published: 7 February 2021

Publisher's Note: MDPI stays neutral with regard to jurisdictional claims in published maps and institutional affiliations.

Copyright: (c) 2021 by the authors. Licensee MDPI, Basel, Switzerland. This article is an open access article distributed under the terms and conditions of the Creative Commons Attribution (CC BY) license (https:// creativecommons.org/licenses/by/ $4.0 /)$.

\begin{abstract}
Based on the continuous increase of donor risk, with a majority of organs classified as marginal, quality assessment and prediction of liver function is of utmost importance. This is also caused by the notoriously lack of effective replacement of a failing liver by a device or intensive care treatment. While various parameters of liver function and injury are well-known from clinical practice, the majority of specific tests require prolonged diagnostic time and are more difficult to assess ex situ. In addition, viability assessment of procured organs needs time, because the development of the full picture of cellular injury and the initiation of repair processes depends on metabolic active tissue and reoxygenation with full blood over several hours or days. Measuring injury during cold storage preservation is therefore unlikely to predict the viability after transplantation. In contrast, dynamic organ preservation strategies offer a great opportunity to assess organs before implantation through analysis of recirculating perfusates, bile and perfused liver tissue. Accordingly, several parameters targeting hepatocyte or cholangiocyte function or metabolism have been recently suggested as potential viability tests before organ transplantation. We summarize here a current status of respective machine perfusion tests, and report their clinical relevance.
\end{abstract}

Keywords: viability testing; machine perfusion; mitochondria; liver transplantation

\section{Introduction}

Machine perfusion technology is increasingly applied in solid organ transplantation to improve the outcomes through a reduction of ischemia-reperfusion injury (IRI) with less complications and better graft survival [1,2]. The principles of dynamic organ preservation were introduced in 1935 with the Lindbergh apparatus, developed to preserve organs, using a pulsatile recirculation of sterile fluid at normothermic temperatures [3]. Since the first clinical application in the 1960, the technology has now significantly evolved [4]. Two main concepts are currently tested in clinical studies. First, the replacement of static cold storage (CS) by perfusion at normothermic $\left(37^{\circ} \mathrm{C}\right)$ or subnomothermic temperatures $\left(34^{\circ} \mathrm{C}\right)$ with a blood-based perfusate with oxygen [5-7]. Second, a concept of organ treatment after CS through perfusion at hypothermic or normothermic/subnomothermic temperatures [8-11]. A few broad indications for this technology are of interest. Liver perfusion to improve organ quality is also directly linked with the need for a reliable methodology of organ viability testing prior to implantation. To explore the large number of available markers, multiple smaller retrospective case studies with diverse perfusion approaches were performed. As a result, a variety of tests is currently considered helpful to classify livers as viable. Of note, many suggested parameters or thresholds, are frequently based on a small number of 
clinical liver transplantations, with a lack of systematic analysis of larger or prospective cohorts. Therefore, most authors suggest a combination of "viability" tests, by composite scores based on quantification of different perfusates parameters [12-17]. However, as most series have only a limited number of events, the correlation of biomarkers with postsurgical outcome remains difficult [18-23]. In this article, we first discuss the clinical relevance of individual parameters, considered for viability testing during machine perfusion before liver transplantation. Second, we highlight certain advantages and disadvantages of suggested markers in context of different perfusion techniques. Finally, we describe the current decision pathways and provide a few suggestions on how to further improve and validate markers currently in clinical use.

\section{What Do We Expect from a Viability Test?}

The term viability carries several definitions in the literature since the earlier days around 1600, when scientists focused on motility to define cellular viability. In biology, viability involves multiple cellular functions dedicated for a single cell or an organism to live, grow, and develop [24]. A more interesting question would be: "What is an appropriate viability test?" or: "How can we determine a proportion of viable cells, tissues, or organs, able to maintain or recover a state of survival?" [24]. Multiple cellular functions are considered to contribute to the status of viability, including cellular morphology, membrane integrity with a functioning barrier, the ability to generate energy to maintain the synthetical function and enzymatic activity, processes of DNA transcription and RNA translation, maintenance of a viable $\mathrm{pH}$ gradient and cellular respiration and reproduction [24]. The main task is now to transform such complex measures in a simple and cheap test, which provides enough confidence to accept an organ for transplantation. The more specific a viability test is, the more complex and time consuming is the required methodology. The best example are the concepts of proteomic, metabolomic, and genomic analyses, which enable specified quantification of almost any circulating molecule in a perfusate or tissue [25]. Despite the expected high accuracy, the clinical practicability of such technology, in form of a real-time test with immediate results, appears however relatively low. Based on this, the expectations toward liver viability assessment are very high and include a quick, cheap, and reliable test, which represents the entire organ. Above all, the aim is to identify a validated parameter threshold, to avoid harmful recipient events after transplantation, provided the cut-off is respected.

\section{Why Is Viability Testing Clinically Relevant?}

With an increasing number of candidates, improved medical management and surgical technology, and an aging population with more comorbidities, the quality of donors has decreased. Currently, the cumulative donor-recipient risk accepted by a team, varies among centers and relies on different levels of experience [26,27]. Most countries have applied thresholds for certain risk factors, when to decline, for example a liver from a donation after circulatory death (DCD) donor [28,29]. Selective allocation of organs from extended criteria donors (ECD) is the current policy to avoid severe IRI with immediate complications, including primary non function (PNF) [30,31]. Although, most cut-off values for standard donor and recipient risk factors are based on the outcomes reported from large retrospective cohort studies, their strict application leads to a high number of discarded livers. To overcome this major obstacle in the field and to better understand the metabolic liver environment, scientists have explored the underlying mechanisms of IRI, a complex metabolic phenomenon, which occurs immediately at normothermic reoxygenation of any mammalian tissue [32-34]. Importantly, no single parameter has been identified yet, to reliably predict the metabolic status of a specific donor liver and the cellular capability to handle ischemia and subsequent reperfusion injury.

As a first step towards the development of a biomarker, it is therefore important to understand the initial trigger of IRI and the downstream consequences. Looking at different cellular compounds, mitochondria appear at front as instigators of the IRI cas- 
cade [35]. During normoxia and aerobic metabolism, mitochondria deliver energy and are crucial for the maintenance of the entire spectrum of cellular functions, considered for a status of viability $[24,36]$. When tissue is exposed to warm or cold ischemia, first the mitochondrial electron transport and respiration is on hold, based on a complex I-V dysfunction. Subsequently there is a lack of cellular adenosine triphosphate (ATP) [37-39]. Second, an accumulation of metabolites linked to the tricarboxylic acid (TCA)-cycle, is seen (Figure 1).

a Warm and cold ischemia (Hypoxia, during donation and transport)

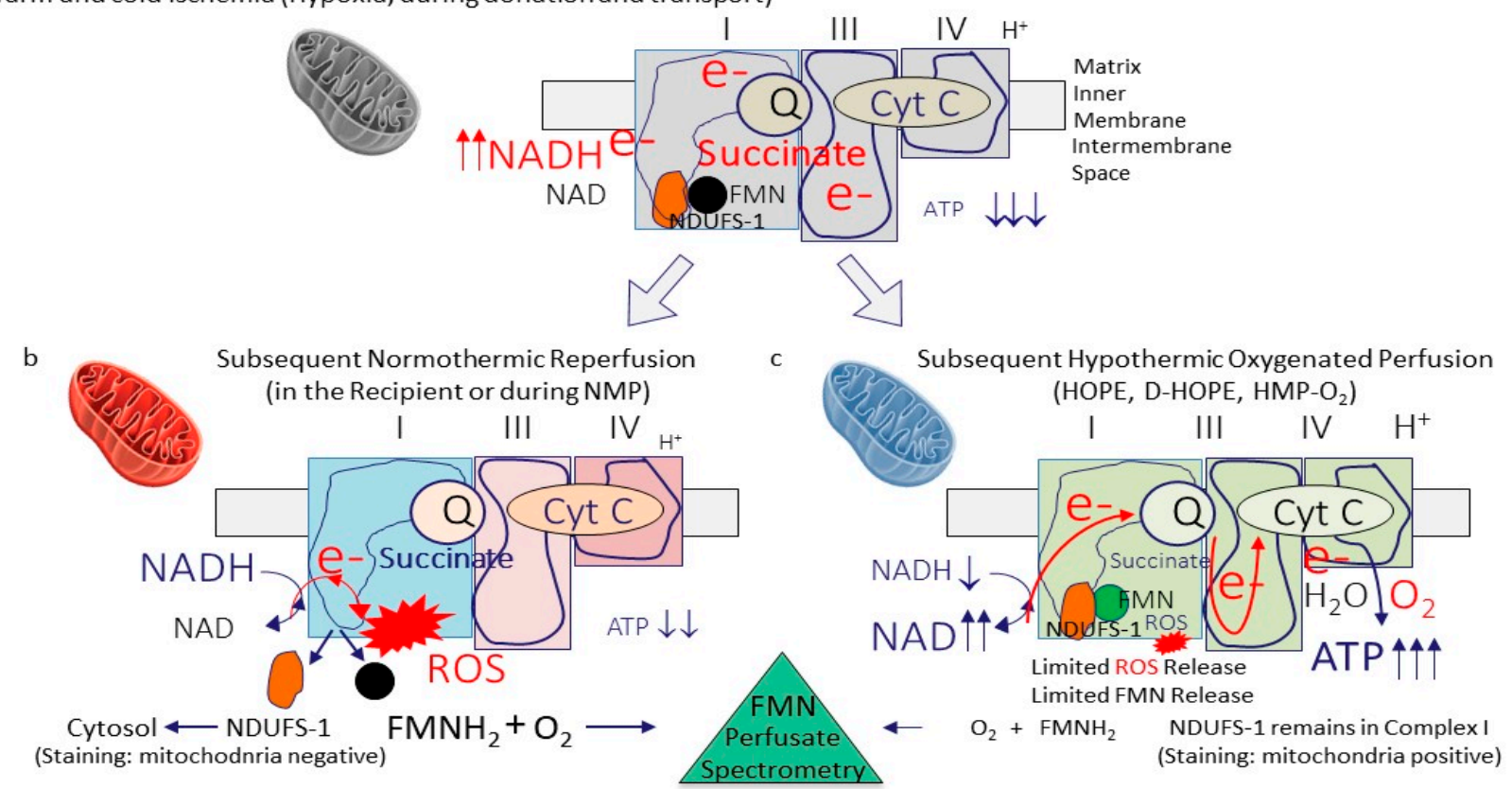

Figure 1. Role of mitochondrial complex I as an instigator of ischemia-reperfusion injury. During any sort of warm or cold ischemia, the mitochondrial respiration is on hold and leads to a lack of cellular ATP with metabolite accumulation, including succinate. At the same time, the complex-I electron donor NADH accumulates (a). When oxygen is reintroduced, mitochondrial respiration is reinitiated, with a however incongruent speed of the different complexes $1-4$, leading to the development of reactive oxygen species (ROS), the initiator molecule of further downstream tissue inflammation. Flavin-mononucleotide $\left(\mathrm{FMNH}_{2}\right)$ are released from the same area in complex I, next to the ROS molecules. Together with damps and cytokines, such molecules react with oxygen and are released into the circulation, where a spectrophotometric quantification of FMN is possible. This complex 1 injury is significantly more pronounced during normothermic reoxygenation (reperfusion) (b), when compared to reoxygenation under hypothermic conditions (c). The higher the complex 1 injury, the more ROS and FMN molecules are released. Interestingly, NDUFS-1, the complex I FMN pocket, disconnects and is released into the cytosol, where staining procedures are used to quantify the mitochondrial complex 1 injury. ATP: adenosine triphosphate; NAD/NADH: nicotine adenine dinucleotide (oxidized/reduced); ROS: Reactive oxygen species; FMN: flavin mononucleotide; NDUFS-1: NADH: ubiquinone oxidoreductase core subunit S1 (mitochondrial complex I-subunit); $\mathrm{O}_{2}$ : oxygen; Cyt C: cytochrome C; e-: electron; HOPE: hypothermic oxygenate perfusion; D-HOPE: dual hypothermic oxygenate perfusion; HMP: hypothermic machine perfusion; NMP: normothermic machine perfusion.

The TCA is blocked through the functional relation with complex II, the lower temperature during ischemia, and the lack of energy to fuel the enzymatic activity [40,41]. At subsequent rewarming, the four mitochondrial complex proteins restart the electron transfer with an undirected electron transport and the subsequent production and release of reactive oxygen species (ROS) from complex-I (Figure 1).

ROS release appears immediately within the first few minutes after reoxygenation [32,40,42-45]. Importantly, the level of complex-I injury strongly depends on the temperature applied during reoxygenation. Significantly higher levels of mitochondrial injury and dysfunction were found during normothermic reoxygenation, when compared to hypothermic reoxygenation [38]. The substantial recovery from energy loss 
during ischemia was quantified by many historical studies through the measurement of high tissue ATP concentration's after a few hours of liver re-oxygenation under cold conditions $[37,43,46-48]$. The full picture of IRI develops with further downstream inflammation, quantified by Damp- and cytokine release from all cells in perfusates and recipient blood $[43,49]$. Livers, which undergo hypothermic reoxygenation on a device (hypothermic oxygenated perfusion; HOPE/D-HOPE, HMP-O2), experience reprogramming of the mitochondrial respiratory chain with ATP reloading (Figure 1). As a consequence, such organs are protected from IRI features, including ROS-, Damps-, and cytokine release and tissue inflammation at subsequent NMP or transplantation [50,51]. Normothermic machine perfusion (NMP) applied after static cold storage simply exposes the entire picture of IRI and therefore enables the measurement of various molecules released into perfusates. This is considered beneficial by many to develop a test to assess liver viability during NMP [6]. Two strategies appear. First, identify a large number of unspecific parameters and thresholds, requiring artificial intelligence to calculate sort of score points to decide, if a single organ could be used for transplantation [52]. Or second, an easy, cheap, and more precise approach using a few single tests of biomolecules, released from mitochondrial complex I, the key site, where the IRI cascade initiates $[40,53,54]$.

\section{What Are Available Modalities to Test Viability?}

Liver viability assessment starts at the time of donor offer, where the surgeon draws the initial picture during the first conversation with the involved donor coordinator prior to macroscopic examination. With the delivery of the donor past medical history, results of donor blood tests, including liver transaminases, parameters of coagulation, cholestasis, hypoxia and electrolytes, the viability testing begins (Figure 2). In some countries further donor imaging studies are allowed, to perform abdominal ultrasound when for example liver steatosis is expected (Table 1). During procurement surgery organ shape, size, color, flush, and vessel quality are routinely explored. With the available modern technology, results are immediately communicated to the recipient center and further tests are subsequently initiated. For example, liver biopsies are performed at the donor center or sent with a combined transport to the recipient for analysis, or obtained directly by the recipient team when the organ is unpacked from the ice box $[55,56]$. Unless a liver undergoes continuous machine perfusion on a perfusion device, there are limited opportunities to assess the viability further during cold ischemia and transport (Table 1 and Figure 2).

Machine perfusion technology currently evolves significantly, and two main concepts are presently introduced in clinical practice. First, perfusion instead or after limited cold ischemia during transport of the liver and second, an endischemic approach of various machine perfusion concept after initial cold ischemia and transport to the recipient center. Both, normothermic machine perfusion (NMP) or hypothermic machine perfusion (HMP) are beneficial for organ assessment because the recirculation of an oxygenated perfusate uncovers various molecules, released from all liver cells into the perfusate at all temperatures.

Routine blood gas or biochemical analysis were transferred into the field of organ preservation and have been performed either from the cold storage solution or machine perfusates [10,57-59]. The majority of markers is however unspecific, being copied from clinical practice of patients with liver diseases, including for example $\mathrm{pH}$, lactate, or liver transaminases. Further potentially useful tests include perfusate analysis with spectroscopy to quantify specific markers, released from the subcellular compounds (Table 1, Figures 2 and 3). 
Table 1. Overview of different technologies available to assess the donor liver quality during donation, preservation, and transplantation.

\begin{tabular}{|c|c|c|c|c|c|}
\hline Detection Method & Material & $\begin{array}{l}\text { Parameters in } \\
\text { Clinical Use }\end{array}$ & $\begin{array}{l}\text { Time Needed for } \\
\text { Assessment }\end{array}$ & Advantages & Disadvantages \\
\hline $\begin{array}{l}\text { Macroscopic } \\
\text { assessment }\end{array}$ & Entire liver & $\begin{array}{l}\text { Size, perfusion } \\
\text { quality, steatosis, } \\
\text { fibrosis, vessel } \\
\text { quality, injuries }\end{array}$ & Minutes & $\begin{array}{c}\text { Routine, rapid, } \\
\text { non-invasive, } \\
\text { cheap }\end{array}$ & $\begin{array}{l}\text { No information on } \\
\text { function, } \\
\text { imprecise, assessor } \\
\text { dependent }\end{array}$ \\
\hline Ultrasound & Entire liver & $\begin{array}{c}\text { Size, level of } \\
\text { steatosis, lesions }\end{array}$ & $30 \mathrm{~min}$ & $\begin{array}{l}\text { Easy, assessment of } \\
\text { liver parenchyma, } \\
\text { rapid, cheap }\end{array}$ & $\begin{array}{c}\text { Assessor } \\
\text { dependent, no } \\
\text { information on } \\
\text { function }\end{array}$ \\
\hline Fibroscan & Entire Liver & Level of fibrosis & $30 \mathrm{~min}$ & $\begin{array}{l}\text { Non-invasive, } \\
\text { simple, rapid, } \\
\text { reproducible, } \\
\text { non-operator- } \\
\text { dependent }\end{array}$ & $\begin{array}{c}\text { No information on } \\
\text { function, } \\
\text { additional costs }\end{array}$ \\
\hline Histology & Liver tissue & $\begin{array}{l}\text { Level of macro and } \\
\text { microsteatosis, } \\
\text { fibrosis, } \\
\text { inflammation }\end{array}$ & $1-2 \mathrm{~h}$ & $\begin{array}{l}\text { Histological } \\
\text { evidence of quality } \\
\text { provides criteria to } \\
\text { exclude organ } \\
\text { transplantation } \\
\text { (e.g., Fibrosis) }\end{array}$ & $\begin{array}{c}\text { Invasive, } \\
\text { variability in } \\
\text { interpretation, } \\
\text { biopsy covers only } \\
\text { small part of organ, } \\
\text { no information on } \\
\text { function }\end{array}$ \\
\hline $\begin{array}{l}\text { Heamodyn-amics } \\
\text { during Perfusion }\end{array}$ & Entire Liver & $\begin{array}{c}\text { HA \& PV } \\
\text { perfusion flow } \\
\text { (pressure) }\end{array}$ & continuous & Real-Time & $\begin{array}{l}\text { Not specific for cell } \\
\text { type }\end{array}$ \\
\hline Blood gas analysis & $\begin{array}{c}\text { Perfusate, Effluate, } \\
\text { Bile }\end{array}$ & $\begin{array}{c}\text { pO2, } \mathrm{pCO} 2, \\
\text { Lactate, } \mathrm{Na}, \mathrm{K}, \mathrm{pH}, \\
\text { Glucose }\end{array}$ & 5-15 min & $\begin{array}{l}\text { Non invasive, any } \\
\text { type of perfusion, } \\
\text { multiple } \\
\text { parameters, } \\
\text { indirect } \\
\text { cholangiocyte } \\
\text { assessment, } \\
\text { different time } \\
\text { points }\end{array}$ & $\begin{array}{l}\text { Timing, different } \\
\text { parameters, not } \\
\text { specific for a } \\
\text { certain cell type }\end{array}$ \\
\hline $\begin{array}{l}\text { Biochemical } \\
\text { analysis }\end{array}$ & $\begin{array}{l}\text { Perfusate, Effluate, } \\
\text { Bile }\end{array}$ & $\begin{array}{c}\text { AST, ALT, LDH, } \\
\text { HCO3-, ALP }\end{array}$ & $5-15 \mathrm{~min}$ & $\begin{array}{l}\text { Non-invasive, } \\
\text { indirect } \\
\text { cholangiocyte } \\
\text { assessment, } \\
\text { different time } \\
\text { points }\end{array}$ & $\begin{array}{l}\text { Not specific for a } \\
\text { certain cell type, } \\
\text { no functional } \\
\text { assessment, no } \\
\text { reliable prediction } \\
\text { of outcomes after } \\
\text { transplantation }\end{array}$ \\
\hline Spectroscopy & Perfusate, Effluate & FMN, NADH & $5-15 \mathrm{~min}$ & $\begin{array}{l}\text { Easy, quick, cheap, } \\
\text { reliable prediction } \\
\text { of graft function, } \\
\text { covers entire organ, } \\
\text { any type of } \\
\text { machine perfusion }\end{array}$ & $\begin{array}{l}\text { No discrimination } \\
\text { between different } \\
\text { cell types }\end{array}$ \\
\hline $\begin{array}{c}\text { Metabolomics/ } \\
\text { proteomics / } \\
\text { genomics }\end{array}$ & $\begin{array}{c}\text { Liver tisue, } \\
\text { perfusate, effluate, } \\
\text { bile }\end{array}$ & $\begin{array}{l}\text { Various molecules } \\
\text { from all cellular } \\
\text { and sub-cellular } \\
\text { compounds }\end{array}$ & Days/Weeks & $\begin{array}{c}\text { Multiple } \\
\text { parameters, can be } \\
\text { performed in any } \\
\text { material (tissue, } \\
\text { perfusate, bile) }\end{array}$ & $\begin{array}{l}\text { Requires long time, } \\
\text { expensive, not } \\
\text { specific for a } \\
\text { certain cell type }\end{array}$ \\
\hline
\end{tabular}




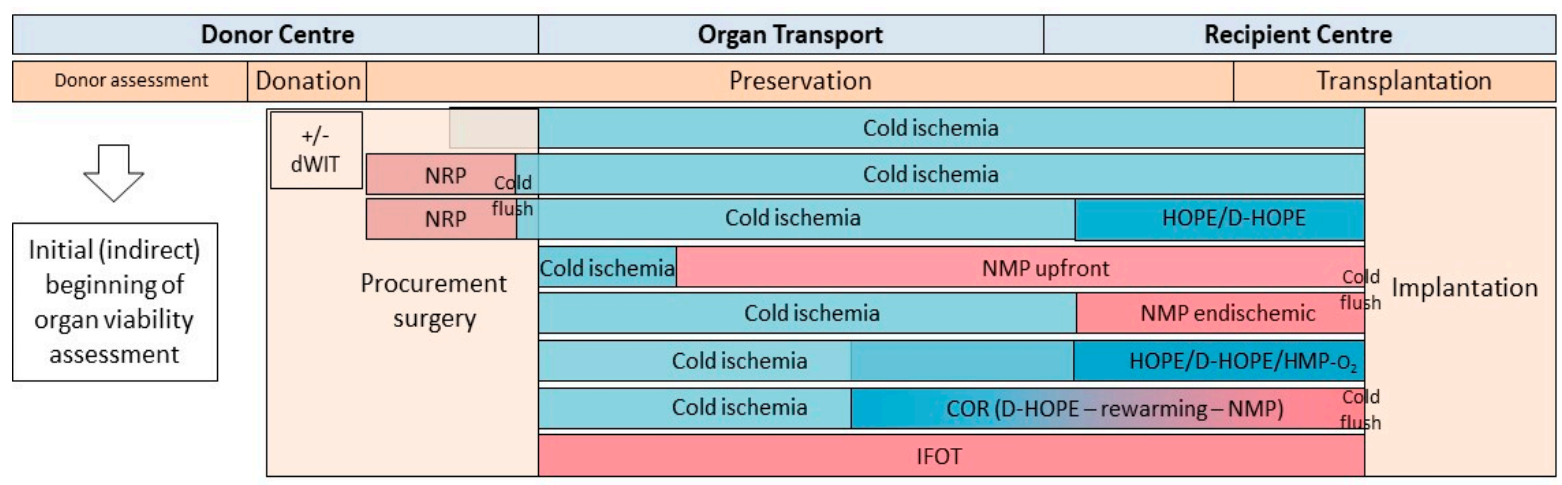

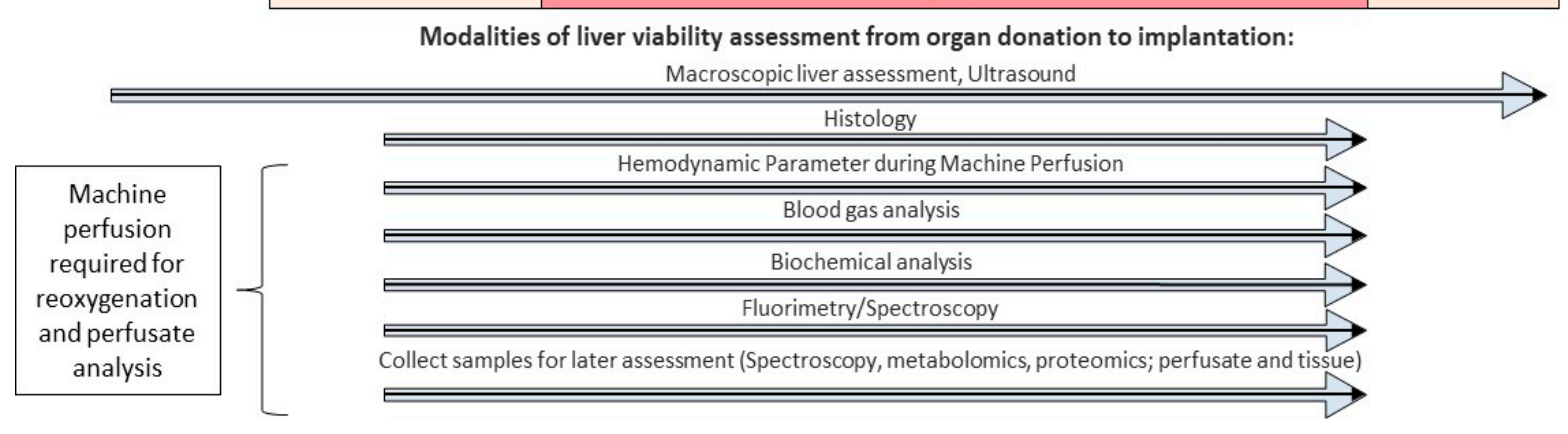

Figure 2. Timeline and modalities to assess viability from organ donation, during preservation, and transplantation. Various tests and modalities contribute to the overall picture of viability assessment during organ preservation. Dynamic preservation methods provide various advantages to sample perfusate, bile, and tissue for parameter quantification. dWIT: donor warm ischemia time; NRP: normothermic regional perfusion; COR: controlled oxygenated rewarming; HOPE: hypothermic oxygenate perfusion; D-HOPE: dual hypothermic oxygenate perfusion; HMP: hypothermic machine perfusion; IFOT: ischemia free organ transplantation; NMP: normothermic machine perfusion.

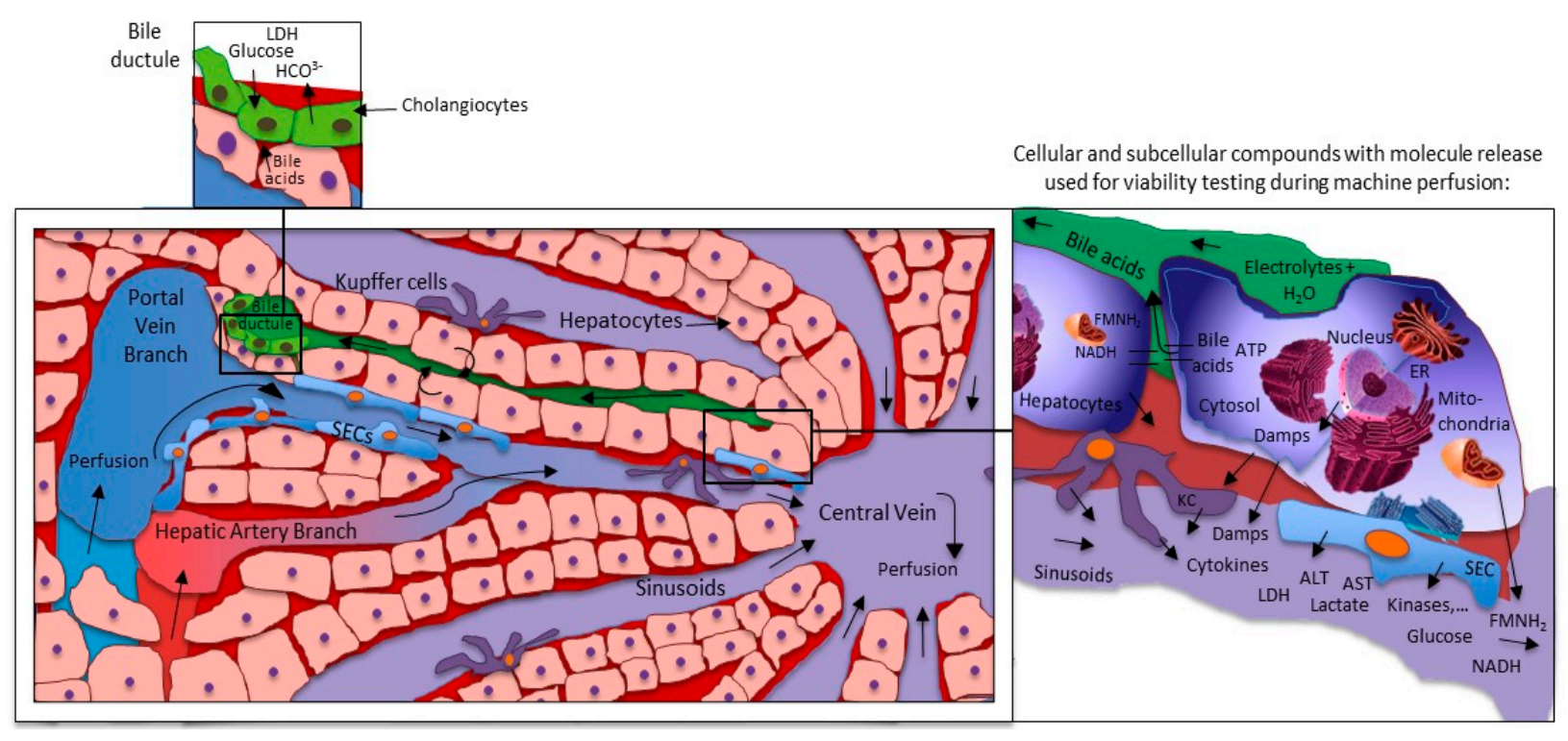

Figure 3. Liver machine perfusion and marker release on cellular and sinusoidal level. Every cellular compound release molecules of injury during reperfusion. Hepatocytes appear at front, also due to their number in the liver. The majority of molecules are simply washed out into the circulation or perfusates. Only very few represent the metabolic situation of the organ and the task is their identification. ER: endoplasmic reticulum; KC: Kupffer cells; SECs: sinusoidal endothelial cells; $\mathrm{LDH}$ : lactate dehydrogenase; $\mathrm{HCO}^{3-}$ : monohydrogencarbonate; ALT: alanine aminotransferase; AST: aspartateaminotransferase; ATP: adenosine triphosphate; Damps: danger associated molecular patterns; NAD/NADH: nicotine adenine dinucleotide (oxidized/reduced); ROS: reactive oxygen species; FMN: flavin mononucleotide; NDUFS-1: NADH: ubiquinone oxidoreductase core subunit S1 (mitochondrial complex I-subunit). 
Although this technology is also not new, it was recently implemented to quantify molecules used for viability assessment during HOPE treatment $[23,38]$. Other than perfusate or flush solution, the fluid released through the biliary tree during NMP is used to indirectly measure hepatocyte and cholangiocyte injury or function. Bile parameters include $\mathrm{pH}$, bicarbonate and glucose concentration, and lactate dehydrogenase (LDH) $[19,60]$. Perfusates, bile and tissues can be obtained throughout the entire time an organ is exposed to dynamic perfusion modalities. A large body of tests, including the LIMAX test, the quantification of miRNA, mitochondrial DNA or Damps and cytokines, metabolomic/proteomic/genomic analyses, and ATP quantification, could be applied [25,61-63]. Clinical use of such modalities is limited by the prolonged time required to receive a result, or the need for tissue biopsies, where a systematic analysis to identify the best marker combination is still lacking today.

\section{What Is More Important: Liver Injury or Function?}

Livers with more than 108 cells per gram weight are the metabolic power house in our bodies and accomplish more than 500 functions [64]. Perfusate analysis with metabolomic technologies reveal several thousand molecules, released from one single organ. Such molecules can be classified according to their origin in different cellular compounds including cytosol, mitochondria, endoplasmic reticulum (ER), or nucleus (Figure 3). In addition, various protein classes, including damps, cytokines, chemokines, kinases, and heat shock proteins can be used to group those molecules, known from experimental studies as markers to describe the level of IRI [43,65-67]. The challenge is now, how to best identify those parameters, which represent the metabolic liver function under healthy conditions, and are also relevant for viability testing during machine perfusion. The best example are liver transaminases, routinely measured to explore the level of liver injury before and after liver resection or transplantation, both aspartate-aminotransferase (AST) and alanine-aminotransferase (ALT) appear very unspecific with a limited predictive value [68]. Similarly, perfusate or plasma damps and cytokines are frequently measured in experimental studies to describe the tissue response to injury or to a specific treatment. The required technology with ELISA or PCR appears time consuming with several hours to day of analysis and are less practical in the setting of machine perfusion.

Hibernators induce changes in their cellular respiration through mitochondria, which further highlights their relevance. Of note, hibernating animals are naturally protected from IRI during periods of arousal, when returning to normal cellular functions and temperature $[69,70]$. Based on this and the known key instigator of IRI, situated in mitochondria, such compounds appear at front to describe the function or viability of an organ, including the liver $[36,45,71]$. This is further supported by Sumimoto et al. who nominated mitochondrial ATP production as a reliable marker for viability in 1988 [72]. Energy is of utmost importance for any cellular process and highlights the need for proper mitochondrial function. Today, the quantification of cellular ATP requires several hours and thereby does not represent a useful marker for real-time viability testing, while an organ is on a perfusion device. Measurement of surrogate markers for ATP recovery during machine perfusion, which represent the metabolic situation of the complex I and II in the respiratory chain, is needed.

\section{How Do We Test Viability during Normothermic Machine Liver Perfusion?}

Normothermic machine perfusion (NMP) is nominated by many as the best perfusion approach to assess organ viability $[59,73]$. Various authors claim this technology provides "near-physiological" conditions, although the question, what circumstances from organ donation, transport and transplantation are really physiological? appears $[9,10,74]$.

Two main groups of parameters, selected as "viability criteria," are in clinical use during NMP to differentiate between liver cells (hepatocytes) and the biliary tree. Additional parameters of perfusion quality, metabolic, and excretory organ function are used to explore how viable a specific organ appears. In 2020, Raigani et al. have demonstrated 
the median costs of $\$ 28,099$ USD needed to identify a potentially transplantable liver with NMP in the US [17].

\subsection{Perfusion Quality and Hemodynamic Parameter}

Parameters of perfusion quality are routinely considered as surrogate marker for liver function. Vascular resistance contributes to perfusion flows, which are also dependent on perfusion pressure. An increased vascular resistance has been linked with a generally impaired liver function [75]. Livers with significant levels of macrosteatosis may experience narrowing of the sinusoids with subsequent reduced perfusion flows [76]. One consequence of sinusoidal obstruction due to fat droplets or to stuck blood cells during reperfusion is a reduced flow, which leads to secondary hypoxia. These features induce an additional aggravation of IRI with ROS, Damps, and cytokine release and ongoing inflammation with organ dysfunction. Perfusion quality is therefore an important parameter. High resistance has been a sign of organ injury and later dysfunction. Stable perfusion flow rates during NMP were therefore suggested by many $[22,59,60]$. A few authors have defined more specific viability criteria with a portal vein and hepatic artery flow above $>500 \mathrm{~mL} / \mathrm{min}$ and $>150 \mathrm{~mL} / \mathrm{min}$, respectively (Table 2 ) $[9,57,74]$. Some case series described a reduction in flow rates toward the end of prolonged NMP, a sign of sinusoidal exhaustion and advanced injury [12]. However, when an impaired flow and high resistance is present, an advanced injury is usually seen on histological examination. Parameters of perfusion quality are therefore rather late signs of a failing organ, which might explain, why most studies failed to discriminate between viable and non-viable livers based on the perfusion flows only $[20,60,77]$.

\subsection{How Helpful Is the Quantification of Liver Transaminases?}

The level of transaminases measured in perfusate is another unspecific parameter with many confounders. Prolonged perfusion first, induces hemolysis and leads to additional AST release from erythrocytes. In contrast, a very advanced-injured liver does not release more transaminases into perfusate, due to the "empty hepatocytes," interpreted as "false low." Cut-off values are largely missing and those suggested by various groups appear arbitrary. Clinically applied AST and ALT thresholds range from 6000 to $9000 \mathrm{U} / \mathrm{L}$ (Table 2) $[21,60,78]$. Ceresa et al. have discarded one graft in their trial based on an ALT of $9268 \mathrm{U} / \mathrm{L}$ in the first hours of NMP [21]. The group from Innsbruck has declined 4 grafts due to an "inadequate high perfusate AST" [78]. Livers with very high transaminase release are quickly classified as "non-viable," while low values are unspecific, and both scenarios are challenging. Although transaminases could be normed to liver weight and perfusate fluid to improve the predictive value, their correlation with outcome parameters was always weak in clinical studies [68]. 


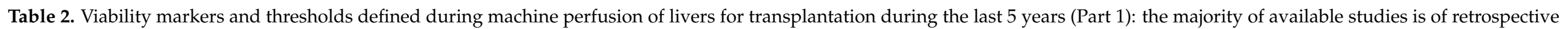

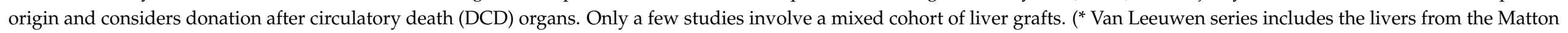
series; " Watson series from 2018 includes the series from 2017; graft related relevant complications include PNF, IC or ITBL, AS or leaks, number of EADs was not listed).

\begin{tabular}{|c|c|c|c|c|c|c|}
\hline Author \& Year & Country & $\begin{array}{l}\text { Number and Type } \\
\text { of Livers }\end{array}$ & $\begin{array}{l}\text { Timepoint's } \\
\text { and Modality }\end{array}$ & $\begin{array}{l}\text { Viability Criteria } \\
\text { and Threshold }\end{array}$ & $\begin{array}{c}\text { Prospective } \\
\text { Decision Making }\end{array}$ & $\begin{array}{l}\text { Events below the } \\
\text { Threshold } \\
\text { (within Criteria) }\end{array}$ \\
\hline \multicolumn{7}{|c|}{ Hypothermic Machine Perfusion (HOPE, D-HOPE) } \\
\hline Schlegel et al., 2020 & Switzer-land & $\begin{array}{l}50 \text { perfused and } \\
\text { transplanted } \\
(32 \mathrm{DCD}, 18 \mathrm{DBD}, \mathrm{HOPE})\end{array}$ & $\begin{array}{l}\text { Serial measurements } \\
\text { (perfusate and tissue) by } \\
\text { mass spectometry and } \\
\text { spectroscopy, at } 15,30,60 \\
\text { and } 90 \text { min and end of } \\
\text { HOPE }\end{array}$ & $\begin{array}{l}\text { Perfusate, tissue and } \\
\text { mitochondria: } \\
\text { FMN at } 30 \text { min (<8800 A.U. or } \\
\text { sharp incline), } \\
\text { NADH (<10,000 A.U.) }\end{array}$ & Yes $(n=16 / 50)$ & $\begin{array}{l}1 \text { ITBL in retrospective, } \\
\text { development cohort, } \\
\text { none since prospective } \\
\text { application of no PNF }\end{array}$ \\
\hline Patrono et al., 2020 & Italy & $\begin{array}{l}50 \text { perfused and } \\
\text { transplanted (ECD DBD, } \\
\text { D-HOPE) }\end{array}$ & $\begin{array}{l}\text { Every } 30 \mathrm{~min} \\
(3 \mathrm{~h} \text { perfusion })\end{array}$ & $\begin{array}{l}\text { Perfusate Lactate, AST, ALT, } \\
\text { LDH, glucose, and pH }\end{array}$ & No & $\begin{array}{l}\text { No threshold applied, } \\
3 \text { months follow up }\end{array}$ \\
\hline Muller et al., 2019 & Switzer-land & $\begin{array}{l}100 \text { perfused and } \\
\text { transplanted } \\
(80 \mathrm{DCD}, 20 \mathrm{DBD}), \\
54 \text { assessed, HOPE }\end{array}$ & $\begin{array}{l}\text { Serial perfusate } \\
\text { measurements by mass } \\
\text { spectometry and } \\
\text { spectroscopy, at 15, 30, and } \\
60 \text { min and end of HOPE }\end{array}$ & $\begin{array}{l}\text { Perfusate FMN at } 30 \mathrm{~min} \\
\text { (<8800 A.U.) }\end{array}$ & No & $\begin{array}{l}\text { Threshold established } \\
\text { retrospectively }\end{array}$ \\
\hline \multicolumn{7}{|c|}{ Normothermic Machine Perfusion (NMP, NMP after COR) } \\
\hline Mergental et al., 2020 & UK & $\begin{array}{l}31 \text { perfused, } \\
22 \text { transplanted (12 DBD, } \\
10 \text { DCD) }\end{array}$ & $\begin{array}{l}\text { Serial measurements every } \\
30 \mathrm{~min} \\
\text { Assessment at } 2.5 \text { and } 4 \mathrm{~h}\end{array}$ & $\begin{array}{l}\text { Within } 4 \mathrm{~h} \text { of NMP: lactate } \\
<2.5 \mathrm{mmol} / \mathrm{L} \text { and } \geq 2 \text { of the } \\
\text { following criteria: } \\
\text { 1. Evidence of bile production; } \\
\text { 2. } \mathrm{pH}>7.30 \text {; } \\
\text { 3. Metabolism of glucose; } \\
\text { 4. HA flow }>150 \mathrm{~mL} / \mathrm{min} \text { and } \\
\text { PV flow }>500 \mathrm{~mL} / \mathrm{min} \text {; } \\
5 \text {. Homogenous perfusion }\end{array}$ & Yes & $\begin{array}{l}2 \text { anastomotic strictures } \\
4 \text { ITBL with } \\
\text { retransplantation } \\
6 \text { months follow up }\end{array}$ \\
\hline
\end{tabular}


Table 2. Cont.

\begin{tabular}{|c|c|c|c|c|c|c|}
\hline Author \& Year & Country & $\begin{array}{l}\text { Number and Type } \\
\text { of Livers }\end{array}$ & $\begin{array}{l}\text { Timepoint's } \\
\text { and Modality }\end{array}$ & $\begin{array}{l}\text { Viability Criteria } \\
\text { and Threshold }\end{array}$ & $\begin{array}{c}\text { Prospective } \\
\text { Decision Making }\end{array}$ & $\begin{array}{l}\text { Events below the } \\
\text { Threshold } \\
\text { (within Criteria) }\end{array}$ \\
\hline Cardini et al., 2020 & Austria & $\begin{array}{l}34 \text { perfused, } \\
25 \text { transplanted ( } 21 \mathrm{DBD}, \\
4 \text { DCD) }\end{array}$ & $\begin{array}{l}\text { Serial measurements every } \\
\text { hour until } 6 \text { h NMP, } \\
\text { afterwards every } 2 \mathrm{~h}\end{array}$ & $\begin{array}{l}\text { 1. Rapid decrease and } \\
\text { maintenance of lactate levels } \\
\text { (first } 2 \text { h of NMP); } \\
\text { 2. Bile output and biliary pH; } \\
\text { 3. Maintenance of physiological } \\
\text { perfusate pH without sodium } \\
\text { bicarbonate; } \\
\text { 4. Exceptionally high OR sharp } \\
\text { incline of AST, ALT, LDH }\end{array}$ & Yes & $\begin{array}{l}\text { No PNF } \\
7 \text { anastomotic strictures } \\
3 \text { bile leaks } \\
1 \text { left hemihepatectomy } \\
\text { (ascending cholangitis } \\
\text { after stricture) } \\
20 \text { months follow up }\end{array}$ \\
\hline Zhang et al., 2020 & China & $\begin{array}{l}4 \text { perfused and } \\
\text { transplanted } \\
(1 \mathrm{DBD}, 3 \mathrm{DCD})\end{array}$ & $\begin{array}{l}\text { Serial measurements } \\
\text { perfusate BGA every } \\
10 \mathrm{~min} \text { for the first } 40 \mathrm{~min} \text {, } \\
\text { and then every } 20 \mathrm{~min} . \\
\text { Bile collected every hour }\end{array}$ & $\begin{array}{l}\text { Within } 4 \mathrm{~h} \text { of NMP: } \\
\text { Perfusate lactate } \leq 2.5 \mathrm{mmol} / \mathrm{L} \text {; } \\
\text { 2. Bile production; } \\
\text { 3. Perfusate } \mathrm{pH} \geq 7.30 \text {; } \\
\text { 4. Stable HA flow }> \\
150 \mathrm{~mL} / \mathrm{min} \text { and } \mathrm{PV} \text { flow }> \\
500 \mathrm{~mL} / \mathrm{min}\end{array}$ & Yes & $\begin{array}{l}1 \text { anastomotic stricture } \\
6 \text { months follow up }\end{array}$ \\
\hline Reiling et al., 2020 & Australia & $\begin{array}{l}10 \text { perfused, transplanted } \\
\text { (5 DBD, } 5 \text { DCD) }\end{array}$ & $\begin{array}{l}\text { Serial arterial perfusate } \\
\text { samples } \\
\text { Bile every hour } \\
\text { Biopsies at the retrieval, at } \\
\text { the end of SCS and at the } \\
\text { end of NMP }\end{array}$ & $\begin{array}{l}\text { Within } 2 \mathrm{~h} \text { (to } 4 \mathrm{~h} \text { ) of NMP: } \\
\text { 1. Lactate clearance to } \\
<2 \text { mmol/L } \\
\text { 2. Decreasing trend in perfusate } \\
\text { glucose concentration by } 4 \mathrm{~h} \text {. } \\
\text { 3. Physiological pH without the } \\
\text { need for sodium bicarbonate. } \\
\text { 4. Stable HA and PV flows. } \\
\text { 5. Homogeneous graft perfusion } \\
\text { with soft parenchyma } \\
\text { consistency } \\
\text { 6. Evidence of bile production }\end{array}$ & Yes & $\begin{array}{l}1 \text { Anastomotic leak } \\
1 \text { Anastomotic stricture } \\
6 \text { months follow up }\end{array}$ \\
\hline
\end{tabular}


Table 2. Cont.

\begin{tabular}{|c|c|c|c|c|c|c|}
\hline Author \& Year & Country & $\begin{array}{c}\text { Number and Type } \\
\text { of Livers }\end{array}$ & $\begin{array}{l}\text { Timepoint's } \\
\text { and Modality }\end{array}$ & $\begin{array}{l}\text { Viability Criteria } \\
\text { and Threshold }\end{array}$ & $\begin{array}{c}\text { Prospective } \\
\text { Decision Making }\end{array}$ & $\begin{array}{l}\text { Events below the } \\
\text { Threshold } \\
\text { (within Criteria) }\end{array}$ \\
\hline $\begin{array}{l}\text { Van Leeuwen et al., } \\
2019\end{array}$ & The Netherlands & $\begin{array}{l}16 \text { perfused, } \\
11 \text { transplanted }(\mathrm{DCD}) \text { * }\end{array}$ & $\begin{array}{l}\text { BGA perfusate \& Bile: } \\
\text { Assessment at } 2.5 \mathrm{~h} \\
\text { (Trial: } \\
\text { D-HOPE-COR-NMP) }\end{array}$ & $\begin{array}{l}\text { After } 2.5 \mathrm{~h} \text { of NMP: } \\
\text { 1. Lactate clearance to } \\
\leq 1.7 \mathrm{mmol} / \mathrm{L} \text {; } \\
\text { 2. Perfusate } \mathrm{pH} 7.35-7.45 \text {; } \\
\text { 3. Bile production }>10 \mathrm{~mL} \text {; } \\
\text { 4. Biliary } \mathrm{pH}>7.45\end{array}$ & Yes & $\begin{array}{l}1 \text { ITBL } \\
3 \text { Anastomotic strictures } \\
\text { Median follow up } \\
12 \text { months }\end{array}$ \\
\hline Matton et al., 2019 & The Netherlands & $\begin{array}{l}\text { (1) } 23 \text { perfused to define } \\
\text { markers; } \\
\text { (2) } 6 \text { perfused, } \\
4 \text { transplanted } \\
\text { (DCD) }\end{array}$ & $\begin{array}{l}\text { BGA perfusate and Bile: } \\
\text { Assessment at } 2.5 \mathrm{~h} \\
\text { (Trial: } \\
\text { D-HOPE-COR-NMP) }\end{array}$ & $\begin{array}{l}\text { After } 2.5 \mathrm{~h} \text { of NMP: } \\
\text { 1. Lactate clearance to } \\
\leq 1.7 \mathrm{mmol} / \mathrm{L} ; \\
\text { 2. Perfusate } \mathrm{pH} 7.35-7.45 ; \\
\text { 3. Bile production }>10 \mathrm{~mL} \text {; } \\
\text { 4. Biliary } \mathrm{pH}>7.48\end{array}$ & Yes & $\begin{array}{l}\text { No relevant graft-related } \\
\text { complications } \\
\text { Median follow up } \\
8.3 \text { months }\end{array}$ \\
\hline Ceresa et al., 2019 & UK & $\begin{array}{l}34 \text { perfused, } 31 \\
\text { transplanted } \\
(23 \mathrm{DBD}, 8 \mathrm{DCD})\end{array}$ & $\begin{array}{l}\text { Perfusate BGA and } \\
\text { Bio-chemistry at } 15 \mathrm{~min} \\
\text { and } 1 \mathrm{~h} \text { of NMP, then every } \\
4 \mathrm{~h} \text {, and the end of NMP }\end{array}$ & $\begin{array}{l}\text { Within } 2.5 \mathrm{~h} \text { and within } 4 \mathrm{~h} \text { : } \\
\text { Lactate clearance and } \\
\text { maintenance, glucose } \\
\text { metabolism, pH maintenance, } \\
\text { bile production, perfusate } \\
\text { transaminase levels }\end{array}$ & Yes & $\begin{array}{l}1 \text { Anastomotic leak } \\
1 \text { Anastomotic stricture } \\
12 \text { months follow up }\end{array}$ \\
\hline De Vries et al., 2019 & The Netherlands & $\begin{array}{l}7 \text { perfused, } \\
5 \text { transplanted } \\
(\mathrm{DCD})\end{array}$ & $\begin{array}{l}\text { BGA perfusate \& Bile: } \\
\text { Assessment at } 2.5 \mathrm{~h} \\
\text { (Trial: } \\
\text { D-HOPE-COR-NMP) }\end{array}$ & $\begin{array}{l}\text { After } 2.5 \mathrm{~h} \text { of NMP: } \\
\text { 1. Lactate clearance to } \\
\leq 1.7 \mathrm{mmol} / \mathrm{L} \text {; } \\
\text { 2. Perfusate pH } 7.35-7.45 ; \\
\text { 3. Bile production }>10 \mathrm{~mL} \text {; } \\
\text { 4. Biliary } \mathrm{pH}>7.45\end{array}$ & Yes & $\begin{array}{l}\text { No relevant graft-related } \\
\text { complications } \\
\text { Median follow up } \\
6.5 \text { months }\end{array}$ \\
\hline
\end{tabular}


Table 2. Cont

\begin{tabular}{|c|c|c|c|c|c|c|}
\hline Author \& Year & Country & $\begin{array}{c}\text { Number and Type } \\
\text { of Livers }\end{array}$ & $\begin{array}{l}\text { Timepoint's } \\
\text { and Modality }\end{array}$ & $\begin{array}{l}\text { Viability Criteria } \\
\text { and Threshold }\end{array}$ & $\begin{array}{c}\text { Prospective } \\
\text { Decision Making }\end{array}$ & $\begin{array}{l}\text { Events below the } \\
\text { Threshold } \\
\text { (within Criteria) }\end{array}$ \\
\hline Watson et al., 2018 & UK & $\begin{array}{l}47 \text { perfused, } \\
22 \text { transplanted } \\
(16 \mathrm{DCD}, 6 \mathrm{DBD}){ }^{\#}\end{array}$ & $\begin{array}{l}\text { BGA + Biochemistry: at } 10 \\
\text { and } 30 \mathrm{~min} \text {, every } 30 \mathrm{~min} \\
\text { thereafter }\end{array}$ & $\begin{array}{l}\text { 1. Peak lactate fall } \geq \\
4.4 \mathrm{mmol} / \mathrm{L} / \mathrm{kg} / \mathrm{h} \\
2 . \text { ALT }<6000 \mathrm{iU} / \mathrm{L} \text { at } 2 \mathrm{~h} \\
\text { 3. Maximum bile } \mathrm{pH}>7.5 \\
\text { 4. Bile glucose } \leq 3 \mathrm{mmol} / \mathrm{L} \text { or } \\
10 \text { mmol less than perfusate } \\
\text { glucose } \\
5 . \text { Maintain perfusate } \mathrm{pH}>7.2 \\
\text { with } \leq 30 \mathrm{mmol} \\
\text { bicarbonate supplementation } \\
\text { 6. Falling glucose beyond } 2 \mathrm{~h} \\
\text { OR perfusate glucose }< \\
10 \text { mmol/L with subsequent fall } \\
\text { during challenge with } 2.5 \mathrm{~g} \\
\text { glucose }\end{array}$ & Yes & $\begin{array}{l}1 \text { PNF } \\
4 \text { ITBL (3 with } \\
\text { retransplantation or } \\
\text { awaiting) } \\
\text { Median follow up } \\
20 \text { months }\end{array}$ \\
\hline Bral et al., 2017 & Canada & $\begin{array}{l}9 \text { perfused and } \\
\text { transplanted } \\
4 \mathrm{DCD}, 6 \mathrm{DBD}\end{array}$ & $\begin{array}{l}\text { At perfusion start and } \\
\text { every } 2 \mathrm{~h}\end{array}$ & $\begin{array}{l}\text { pH, Lactate, ALT, AST, bilirubin, } \\
\text { perfusion vascular stability, } \\
\text { hourly bile production }\end{array}$ & No & $\begin{array}{l}\text { No PNF, one early HCV } \\
\text { recurrence with graft } \\
\text { loss, } 6 \text { months follow up }\end{array}$ \\
\hline Mergental et al., 2016 & UK & $\begin{array}{l}6 \text { perfused } \\
5 \text { transplanted } \\
(4 \mathrm{DCD}, 1 \mathrm{DBD})\end{array}$ & Every $30 \mathrm{~min}$ and at $3 \mathrm{~h}$ & $\begin{array}{l}\text { Within } 3 \mathrm{~h} \text { of NMP: Lactate } \\
\text { clearance to }<2.5 \mathrm{mmol} / \mathrm{L} \text { or } \\
\text { evidence of bile production } \\
\text { combined with two of the } \\
\text { following criteria: } \\
\text { 1. Perfusate } \mathrm{pH}>7.30 \\
2 \text {. Hepatic artery flow }> \\
150 \mathrm{~mL} / \mathrm{min} \text { and portal vein } \\
\text { flow }>500 \mathrm{~mL} / \mathrm{min} \\
3 \text {. Homogenous perfusion with } \\
\text { soft parenchyma consistency }\end{array}$ & Yes & $\begin{array}{l}\text { No relevant graft-related } \\
\text { complications } \\
\text { Median follow up } \\
7 \text { months }\end{array}$ \\
\hline
\end{tabular}




\subsection{What Is the Predictive Value of Lactate?}

Although lactate is the most prominent parameter, used to assess the viability during NMP, the predictive value is limited. The key question here is to understand, why we fail to distinguish between viable and non-viable livers based on perfusate lactate measurements? During warm or cold ischemia, mitochondria experience hypoxia and respiratory failure with subsequent switch to anaerobic glycolysis. Lactate is produced from pyruvate by lactate dehydrogenase under anaerobic conditions (hypoxia).

Importantly, lactate metabolism or clearance to glucose or glycogen requires oxygen and ATP [79]. During normothermic reperfusion in the recipient or on a perfusion device, lactate measurements show a curve with three phases, an initial high peak with a fairly rapid clearance, followed by a maintenance phase with stable and low lactate values between 2 and $4 \mathrm{mmol} / \mathrm{L}$. Lactate clearance mainly occurs in periportal hepatocytes, representing zone one of the liver lobule, which is the last zone exposed to oxygen deprivation. In contrast, hepatocytes in zone two and three, both with more distance from the portal triad, contribute less to lactate clearance. Such variations in liver metabolism further support recent findings, that a persistently elevated lactate is a sign of advanced, panlobular injury and liver dysfunction in a late stage or an ongoing lactate production from hypo-perfused parenchyma [58].

Although ex situ perfusion circuits include only the liver, lactate is also released from erythrocytes, particularly when the perfusion duration is prolonged (more than $24 \mathrm{~h}$ ) [64]. An additional challenge is the multiple suggested thresholds for lactate in the literature. Based on experimental studies that identified a combination of perfusate lactate, bile production, and stable perfusion flows as "reliable" predictors of graft viability, the group from Birmingham initially suggested lactate as the key parameter. In 2016, Mergental et al. published the outcome of 5 human livers, transplanted after NMP. Liver grafts were accepted when lactate clearance to $\leq 2.5 \mathrm{mmol} / \mathrm{L}$ was achieved within the first $3 \mathrm{~h}$ of NMP or when the organ met a combination of other parameters, including bile production, perfusion quality, and perfusate $\mathrm{pH}$ of $>7.3$ [80].

Next, the same group presented a cohort study of 12 livers. Grafts were divided into a lactate clearing (LC)- and a non-LC group, where lactate levels showed constant fluctuations until the end of $6 \mathrm{~h}$ NMP [14]. Authors performed explicit liver and perfusate assessment without transplantation and demonstrated a link between lactate clearance and bile production, ATP recovery and more healthy histological features.

Based on a clinical experience with their viability criteria in 5 human liver transplantations, the Birmingham group started a new clinical trial, using lactate clearance in combination with other parameters to confidentially decide if livers qualify for transplantation. Within the VITTAL trial, 31 human livers underwent NMP and 22 grafts were transplanted, based on the following criteria: the achievement of lactate clearance to $<2.5 \mathrm{mmol} / \mathrm{L}$, combined with a perfusate $\mathrm{pH}$ of $>7.3$, the evidence of bile production, a homogenous liver perfusion, glucose metabolism and portal vein flow of $\geq 500 \mathrm{~mL} / \mathrm{min}$, and hepatic artery flow rates of $\geq 150 \mathrm{~mL} / \mathrm{min}$ ( $\geq 2$ of the criteria are required to achieve "viability") [9]. Of note, in this trial the assessment period was prolonged to $4 \mathrm{~h}$ to increase the number of utilized livers. Although combined with other parameters, lactate clearance was not predictive enough to protect recipients from the development of 4 ischemic type biliary lesions (ITBL) [9].

In contrast, Reiling et al. applied a threshold of $\leq 2.0 \mathrm{mmol} / \mathrm{L}$ for perfusate lactate, required within the first $2 \mathrm{~h}$ of NMP [59]. Finally, the Groningen group suggested a cut-off $\leq 1.7 \mathrm{mmol} / \mathrm{L}$ lactate during NMP in their cohort studies (Table 2) [81]. Most suggested thresholds appear arbitrary, because of the lack of events, which confirm that transplantation of livers with perfusate lactate beyond such thresholds leads to severe complications, such as PNF (Table 2). Unfortunately, this paradigm is valid for most perfusion parameters, suggested to provide confidence to select livers for implantation.

Another challenge is the timing, when to best measure lactate during perfusion. The various timepoint when to decide to accept a liver or not with 2, 2.5, 3, or $4 \mathrm{~h}$ of NMP 
appear randomly selected due to a lack of sufficient data. Interestingly, in their initial paper published in 2016, the group from Birmingham suggested to quantify lactate after $3 \mathrm{~h}$ of NMP, then moving to $2.5 \mathrm{~h}$ and in their recent VITTAL trial the latest recommendation was $4 \mathrm{~h}$ of NMP $[9,14,80]$.

Following initial lactate clearance, Ceresea et al. have used a second threshold of increasing lactate to $\geq 4 \mathrm{mmol} / \mathrm{L}$ during later perfusion as "warning sign" and discarded 2 livers [21]. Two human livers were also declined in the VITTAL trial because of an increasing lactate after meeting the initial $2 \mathrm{~h}$ criteria [9]. This is paralleled by the frequently remaining high blood lactate, despite continuous hemofiltration in patients with severe acute liver failure. Based on this, lactate is considered as rather late and irreversible sign of significant dysfunction and cell death [82].

Next, individual testing of dialysis components in sophisticated perfusion devices used for prolonged NMP could not achieve lower lactate levels of less than $2.5 \mathrm{mmol} / \mathrm{L}$. These findings underline the fact that even metabolically severely impaired livers have a remaining ability to clear a certain amount of lactate. A study by Watson et al. investigated perfusion characteristic during NMP of 22 transplanted livers. Lactate declined to $\leq 2.5 \mathrm{mmol} / \mathrm{L}$ in all but 5 human livers within two hours. Interestingly, the only liver that suffered a PNF after transplantation, reached this threshold within 90 min of NMP [58,60].

Despite the frequent use of lactate as the "key parameter" to select viable livers, it is a rather unreliable and unspecific marker to test the quality of a specific organ. Of note, Nasralla et al. have observed a PNF in the perfusion arm of their randomized controlled trial, despite sufficient lactate clearance during NMP according to the above mentioned criteria [10].

In this context, the molecule lactate may be more beneficial in predicting organ function when measured more frequently using the area under the curve (AUC), instead of single values. Additionally, each viability parameter, including lactate should be quantified in a more systematic, prospective approach and in a higher number of cases. Third, measured values might be of more relevance when normed to the liver weight and the amount of circulating perfusate. Although lactate represents the anaerobic glycolysis, other markers including cumulative purine metabolites and succinate may provide a more specific picture of oxidative mitochondrial function.

\subsection{Perfusate Acid Balance and $p H$}

Along with advanced donor liver injury or ischemia times, and subsequent tissue hypoxia and anaerobic metabolism, a low perfusate $\mathrm{pH}$ is usually seen during NMP. The majority of case series recommend to maintain a physiological $\mathrm{pH}$ range between 7.3 and $7.45[19,20,74,80,81]$. Many other factors have however impact as confounders, including the perfusate composition and additives. For example, bicarbonate, also used as surrogate marker for viability, is routinely added to perfusate during NMP. The bicarbonate bolus is routinely administered at start of NMP according to perfusate $\mathrm{pH}$, and ranges between 10 and $40 \mathrm{mmol} / \mathrm{L}$ [21]. Watson et al. described in their series, that one liver requiring the administration of $30 \mathrm{mmol}$ bicarbonate during NMP, more than any other graft, has developed a PNF after implantation [60]. Authors have therefore included a maximal bicarbonate bolus of $\leq 30 \mathrm{mmol} / \mathrm{L}$ to maintain a perfusate $\mathrm{pH}$ of $\geq 7.2$ in their criteria (Table 2) [60]. Based on multiple confounders, including the partial pressure of carbon dioxide and the bicarbonate consuming urea production, perfusate $\mathrm{pH}$ and acid balance are considered only in combination with other cellular parameters to determine liver viability. False high or low perfusate $\mathrm{pH}$ values could be the consequence with transplantation of riskier organs or the loss of viable livers deemed of too high risk.

\subsection{Glucose Metabolism}

To mobilize energy from long-term storages, cells switch to anaerobe metabolism when ischemia occurs. The lack of ATP leads to more glycogenolysis, which can be measured 
through elevated glucose levels in perfusates during NMP. Reiling et al. have included the perfusate glucose concentration at $4 \mathrm{~h}$ of NMP in their criteria (Table 2) [59].

The stimulation of gluconeogenesis, while blocking glycogenolysis was recently suggested as supportive test $[12,58,60]$. However, a few confounders need to be discussed. When organs experience severe ischemic injury, glucose can be measured equally low as in metabolically active organs. Based on this, glucose challenge tests have been suggested for viability testing. The addition of glucose to the perfusate is performed to trigger gluconeogenesis, which is only active in cells, capable to perform aerobe metabolism with gluconeogenesis. With a significant proportion of healthy hepatocytes in the liver, the perfusate glucose level decreases $[9,12]$.

Viable livers also metabolize glucose in response to insulin administration, another surrogate for mitochondrial function. The group from Zurich is therefore in favor of such responsive tests to external triggers (such as inulin or vasoactive drugs) instead of simple measurement of single factors. Such challenging tests provide better information particularly when combined with other analyses compared to lactate alone [12,64].

\subsection{How to Assess the "Biliary Tree" during Machine Perfusion?}

Both, healthy hepatocytes and cholangiocytes, contribute to the production and composition of bile in the liver [83]. The large number of hepatocytes actively release bile acids, an ATP-dependent process, which depends on mitochondrial function (Figure 3) [16]. Cholangiocytes release bicarbonate and absorb glucose from bile $[84,85]$. In addition to donor liver quality and the level of IRI, the volume of secreted bile during machine perfusion depends on a proper placement of the bile duct cannula, which can kink and block the bile flow. False low bile flow counts are the consequence.

The group from Groningen suggested a minimal target bile flow of $10 \mathrm{~mL}$ in the first $2.5 \mathrm{~h}$ [81]. However, graft loss has been described despite proper bile production $[58,60]$. Ceresa et al. found 4 livers with no appropriate bile flow within $4 \mathrm{~h}$ of NMP, all were transplanted and showed immediate function and no relevant graft quality-related complications (Table 2) [21]. The four livers, transplanted by Zhang et al. after assessment during NMP showed immediate full function and would have been declined according to the Groningen criteria, because none achieved $10 \mathrm{~mL}$ bile production within the first $2.5 \mathrm{~h}$ of NMP [74]. Such results are further supported by the VITTAL study, where all transplanted livers achieved hepatocyte viability criteria including bile production. However, $45 \%$ of recipients developed some form of irregularities in the bile ducts, seen in the magnetic resonance cholangiography (MRCP). Of note, $18 \%(n=4 / 22)$ required retransplantation for ITBL [9]. The authors of the VITTAL study therefore recommend to avoid transplantation of human DCD livers with prolonged donor warm ischemia time after preservation with endischemic NMP [9]. Next, the group from Cambridge has assessed the utilization of 12 discarded, human livers with endischemic NMP. Despite the achievement of hepatocyte viability, $25 \%$ of recipient developed an ITBL [58].

The majority of studies, which aimed to assess liver viability, focused on hepatocytes. In context of the ITBL incidence, ranging between 2.6 and $33.3 \%$ in the last 10 years of DCD liver transplantation, the interest in cholangiocyte function is increasing [86-88]. Although bile flow is essential to enable assessment of the bile fluid, the predictive value as a single marker to explore the quality of the bile ducts is limited [19]. Cholangiocytes line the main branches of the biliary tree and contribute significantly to the composition of bile, based on their bicarbonate secretion and glucose absorption (Figure 3) [84,85]. In their first series of 12 livers, the group from Cambridge measured the biliary $\mathrm{pH}$ during NMP, and although it was not considered for decision-making, authors were the first to suggest bile $\mathrm{pH}$ as relevant parameter to test viability and the group associated low values with the three ITBLs in their cohort [58].

Three different cut-offs for bile $\mathrm{pH}$ during NMP were suggested in the last 3 years. In their second and main systematic liver viability analysis, the group of Chris Watson has included 47 human livers. Three out of 16 transplanted livers, did not achieve a biliary 
$\mathrm{pH}$ of $>7.4$ and developed an ITBL [60]. Based on 23 human livers, which underwent NMP, Matton et al. have suggested a different bile $\mathrm{pH}$ threshold of $>7.48$. This cut-off was applied in 6 additional perfusions, where 4 livers met criteria and underwent successful transplantation [19]. Four month later, the same group from Groningen however suggested to use a different threshold of bile $\mathrm{pH}$ with $>7.45$ at $2.5 \mathrm{~h}$ in a cohort of $11 \mathrm{DCD}$ livers, transplanted after NMP $(\mathrm{n}=11 / 16)$ (Table 2). Of note, authors applied here a different concept and combined a graft treatment with D-HOPE, followed by controlled oxygenated rewarming (COR) plus viability assessment during NMP. In addition to bile $\mathrm{pH}$, biliary glucose concentrations of $<16 \mathrm{mmol} / \mathrm{L}$ and a bicarbonate level of $>18 \mathrm{mmol} / \mathrm{L}$ should be achieved within $2.5 \mathrm{~h}$ of NMP by livers selected for transplantation [19]. Although all $11 \mathrm{im}-$ planted livers met both, hepatocyte and bile duct viability criteria, one ITBL was seen [81]. Based on this, authors suggested now to follow ratios and deltas between perfusate and bile, instead of absolute values for bicarbonate and glucose [81]. The calculation of biliary over perfusate glucose concentration ratio $(<0.67)$ at $2 \mathrm{~h}$ of NMP, or subtraction of biliary glucose from perfusate glucose at $3 \mathrm{~h}$, were considered [19]. Biliary LDH concentrations of $<$ than $3689 \mathrm{U} / \mathrm{L}$ within $2.5 \mathrm{~h}$ of NMP were further nominated as viability tests for the biliary tree [19]. Livers that met such criteria, were also found with a low bile duct injury (BDI) score on histological examination [19]. Although these are promising steps toward the identification of more reliable markers, the number of overall transplanted grafts remains low (Table 2).

\subsection{Clinical Decision Making Based on Viability Parameter}

Almost each group, or center and surgeon apply not only different perfusion techniques, but also various criteria or parameter thresholds. For example, in Birmingham, livers are routinely assessed macroscopically in the recipient center and undergo NMP, in context of a clinical study and provided the team in favor of this perfusion technology agrees. Specific criteria are then used to accept a liver for transplantation within the first $4 \mathrm{~h}$ of NMP [9]. The lactate threshold used is $\leq 2.5 \mathrm{mmol} / \mathrm{L}$, while the team from Australia considers a perfusate lactate level of $2 \mathrm{mmol} / \mathrm{L}$ as cut-off [59] and the group from Cambridge accepts livers when a peak lactate fall of $\geq 4.4 \mathrm{mmol} / \mathrm{L} / \mathrm{kg} / \mathrm{h}$ is seen [60]. Similar features apply for all other parameters listed in Table 2 . An overview of clinical decision pathway comparing normothermic and hypothermic perfusion approaches with subsequent viability parameters is provided below. Of note, none of the studies has considered different tests, parameters, or thresholds according to the type of graft or the donor age. A generally more severe IRI with subsequent graft dysfunction is reflected by a number of different parameters, which are currently not specific enough to discriminate between metabolically impaired old or young donor grafts or different levels of steatosis. The vast majority of viability test is based on the analysis of DCD liver grafts and subsequently generalized on other graft types.

Such examples of relatively small cohort studies with different perfusion conditions applied during NMP, various molecules tested in perfusate and bile, multiple cut-offs and timepoints suggested for the measurement of individual parameters, impressively demonstrate the enormous variations and confounders in this field. In addition, the work load ahead of us is obvious to identify the most accurate parameter threshold to support a confident decision during NMP. In 2018, Peter Friend already summarized the current state of viability assessment during NMP as follows: "Data from much larger numbers of transplants done with normothermic perfusion (typically from a registry) would be required to determine specific markers of viability." [10].

\section{Viability Assessment during Hypothermic Oxygenated Perfusion}

7.1. Can We Use the Same Parameters as in Normothermic Liver Perfusion?

Hypothermic oxygenate perfusion (HOPE) is routinely applied after cold storage through the portal vein only (or dually through PV and HA; D-HOPE; $\mathrm{HMP}-\mathrm{O}_{2}$ ) with an artificial and high dissolved oxygen concentrations at $8-10{ }^{\circ} \mathrm{C}$ [89]. Results from 
six ongoing randomized controlled trials on cold liver perfusion are currently awaited. Although hypothermic technologies are frequently considered less helpful to assess liver viability, the same molecules found in NMP perfusates can also be identified during cold or subnormothermic liver perfusion (Figures 1, 3 and 4) $[18,23,38,50,65,90]$.

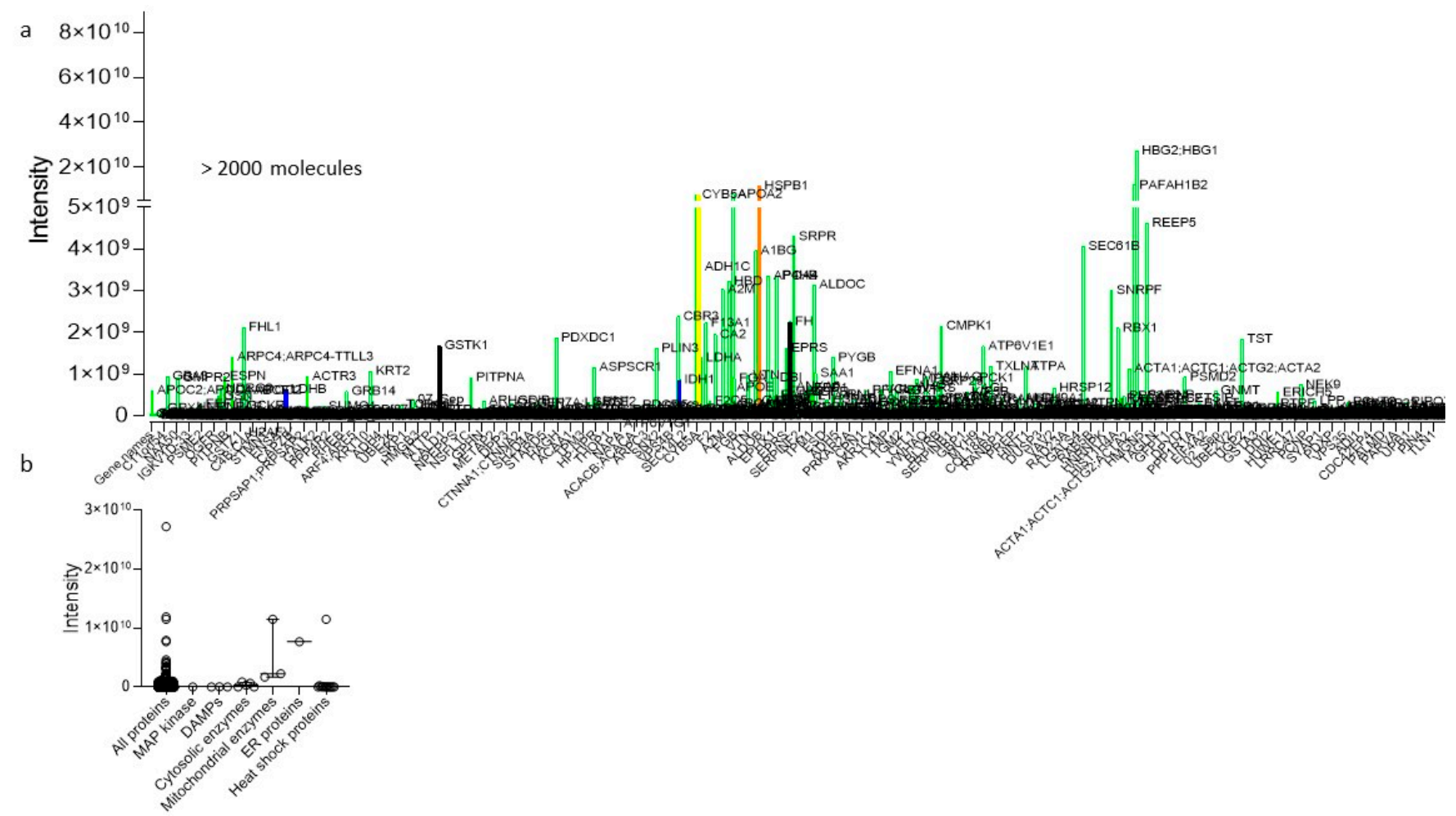

Figure 4. Mass-spectrometry-perfusate analysis, obtained during hypothermic oxygenated perfusion (HOPE). Numerous molecules are identified through mass spectrometry from perfusates obtained during HOPE-treatment of human livers (a). Such molecules were allocated to specific molecule classes released from any cell type (b). HOPE: hypothermic oxygenated perfusion.

Similarly to NMP, perfusion flow, pressures, and resistance are routinely measured, but rarely considered as single criterion for viability testing $[1,8]$. A few retrospective studies have explored the value of the same markers used for viability testing during NMP, in hypothermic perfusates. The predictive value of perfusate lactate, ALT and LDH was assessed systematically in a high-risk DCD liver cohort from Switzerland. Lactate and transaminases were equally ineffective in predicting posttransplant outcomes, similarly to different risk scores, including donor risk index (DRI) and liver graft assessment following transplantation risk (L-GrAFT) score [23]. Perfusate transaminases correlated with posttransplant recipient transaminases, with however no predictive value. Such findings parallel earlier studies, where similar correlation between perfusate and recipient plasma transaminases were demonstrated with however limited further impact on complications [90,91].

Recently, Patrono et al. published the results of a single-center retrospective study on 50 patients, who received a DBD liver transplantation after D-HOPE [18]. Their data showed a negative correlation between lactate and $\mathrm{pH}$ explained by the fact that lactate accumulates during CS as a product of anaerobic glycolysis and when it is subsequently released in the perfusate it determines a reduction of $\mathrm{pH}$. Of note after normalization to liver weight, lactate lost the correlation with markers of hepatocyte and cellular injury (Table 2). In addition, perfusate glucose concentrations failed to predict graft survival during DHOPE, and lactate was the only perfusate parameter not predictive for EAD $[18,23]$. During cold perfusion there is also fluid secretion through the biliary tree, corresponding to 
perfusate mixed with molecules released from hepatocytes into bile, which flow through and between hepatocytes into the sinusoids and ductuli's, following the regular pathway of bile. Recently, the Zurich group has demonstrated a completely fluoresceine-stained liver including the tip of the common bile duct, in the first $5 \mathrm{~min}$ after administration of this dye into the perfusate. Importantly the HOPE was performed through the portal vein only, paralleled by the known venous collateral mesh, fed by the portal vein, and surrounding the common duct $[92,93]$. However, in the cold there is a lack of active secretion of bile acids and other molecules, leading to clear fluid in the biliary tree. This fluid has not been systematically collected and assessed yet.

\subsection{How Can We Assess Mitochondrial Function and Injury?}

The protective effect of hypothermic reoxygenation on mitochondrial function with energy recovery is known from many historical studies [46,94-96]. Important mechanistical differences comparing normothermic and hypothermic reoxygenation were described. Organs exposed to warm and cold ischemia unveil their mitochondrial injury at reperfusion or "reoxygenation" through ROS production and release at complex I, with downstream inflammation of the entire surrounding tissue. Metabolomic perfusate analysis identified a specific protein Flavinmononucleotid $\left(\mathrm{FMNH}_{2}\right)$, released from NDUFS1-a "key pocket" in mitochondrial complex-I, the same localization of ROS production $[34,40,53,54,97,98]$. During physiologic conditions, FMN is tightly bound to complex I. When tissues experience ischemia with subsequent reoxygenation, a certain amount of FMN is released into perfusate or blood, because of the interrupted mitochondrial respiration and the reduction of the ubiquinone pool [99]. The perfusate FMN concentration depends on the liver quality and the temperature applied during reoxygenation. Similarly to the higher level of IRI and ROS, seen during normothermic reperfusion when compared to hypothermic reperfusion, FMN release from complex I is significantly lower under cold conditions (Figure 1) [38]. Galkin et al. have recently demonstrated the importance of the FMN pocket for the ROS production when tissue undergoes normothermic reperfusion [98]. Structural alterations of the pocket may also impact the affinity of FMN and possibly ROS molecules within the mitochondrial complex I.

While the great importance of mitochondrial respiration and energy production is known since more than 30 years, the impact of perfusate FMN as surrogate marker for cellular energy production (ATP) and viability appears new [72]. However, the autofluorescence abilities of FMN have been described in 1969 [100]. High FMN perfusate concentrations correlate with high levels of electron donors and the ATP reduction to precursors, measured by purine metabolites in tissue and perfusates [38]. In contrast to conventional perfusate parameters, such as lactate and transaminases, which failed to predict outcomes after liver transplantation, perfusate FMN concentration correlates with liver function, EAD, hospital stay, cumulative complications, and most importantly 3-month graft loss after liver transplantation with a very high accuracy $[23,38]$. Muller et al. have established a clinically useful threshold of perfusate FMN. If the concentration climbs above 8800 A.U. at $30 \mathrm{~min}$ of HOPE or a sharp incline is seen, authors recommend not to use the liver for implantation. Retrospective analysis has revealed this threshold and $67 \%$ of livers with perfusate FMN levels beyond the threshold were lost (Table 2) [23,38]. Importantly, Guarrera et al. have confirmed the correlation of FMN with posttransplant liver function in perfusates of their ongoing RCTs [101].

In clinical practice, any donor liver with extended risk $(E C D, D C D)$ offered is initially accepted and undergoes HOPE-treatment after standard procurement and transport. The perfusate FMN concentration at 30 min of HOPE treatment is considered the most important variable. If perfusate FMN values are found below 8800 A.U., the liver is accepted for the initially allocated recipient, independent of the recipient's disease severity or MELD score. If there is a sharp FMN incline, a repeat FMN measurement at 45 or 60 min of HOPE perfusion is recommended. If the perfusate concentration climbs further beyond the suggested cut-off, the organ is discarded. If there are high but stable FMN perfusate 
values below the threshold of 8800 A.U., the organ is reallocated to a less sick recipient. Of note, each center follows their specific policy of donor and organ acceptance with various indications for machine perfusion, particularly when applied as compassionate use or outside any clinical trial. Currently used parameters are not assessed for their specificity to discriminate between steatotic livers or DCD grafts for example. However, the FMN threshold described above is valid for DBD grafts and ECD livers of all types including steatotic grafts (Figure 5) [38].

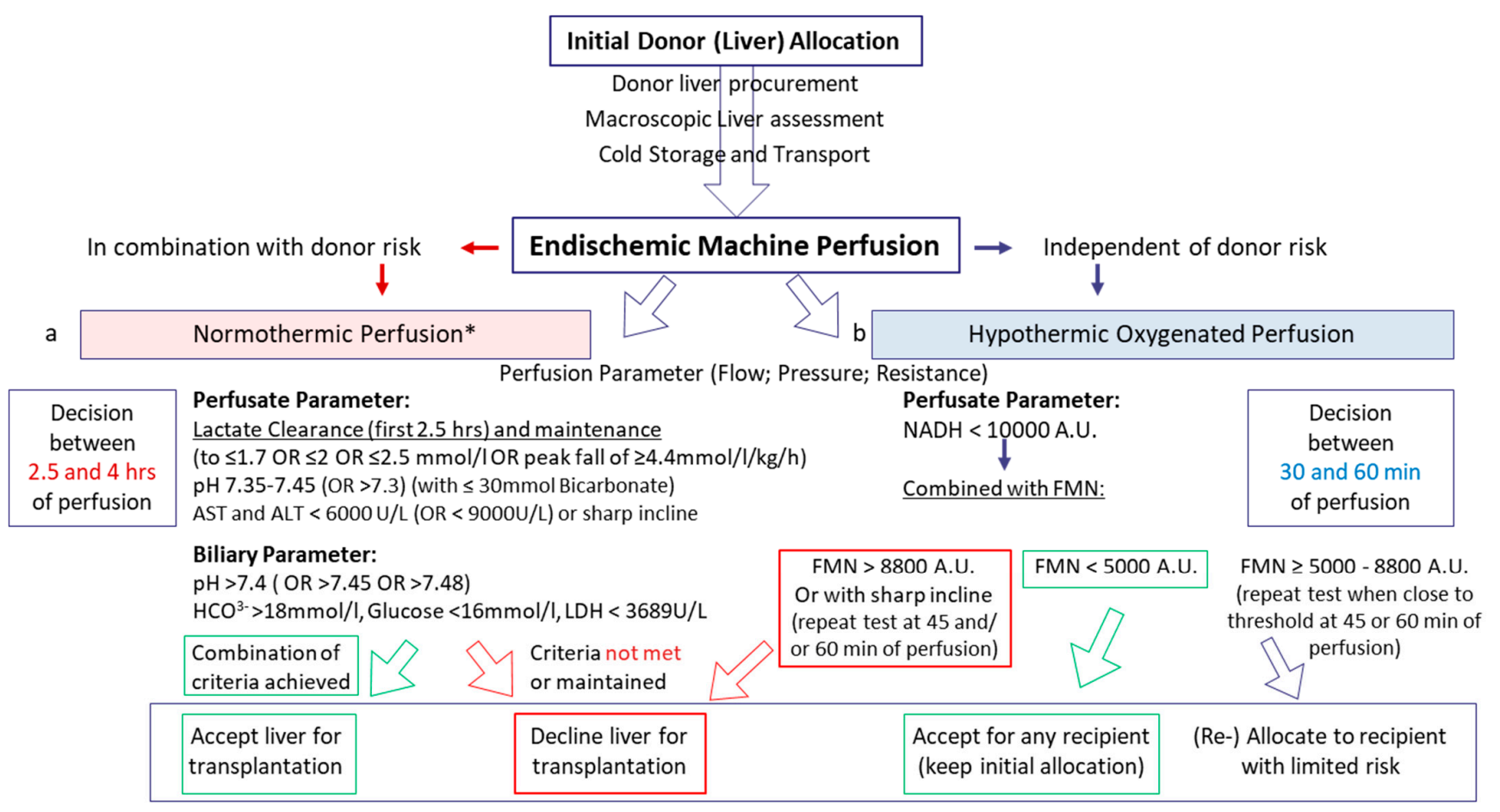

*: includes also NMP after D-HOPE and COR;

Figure 5. Pathway on clinical decision-making based on viability assessment during endischemic machine liver perfusion. Dynamic liver perfusion serves as a tool to test organ quality and to predict function and outcomes after transplantation. Various parameters were suggested for routine clinical use. During normothermic perfusion, parameters of perfusion quality are combined with perfusate analysis. The perfusate lactate concentration below a certain threshold is routinely suggested to be of value to predict the outcome. Further cut-offs are suggested by the literature for perfusate $\mathrm{pH}$, transaminases, and biliary parameter. The majority of decisions is based on the combination of such perfusate analyses during NMP (a). In contrast, molecules with an origin in mitochondria are used during hypothermic oxygenated liver perfusion with a threshold at FMN 8800 A.U. to avoid graft loss (b). Perfusate FMN is routinely combined with NADH concentration, both autofluorescence and measured with a spectrometer during perfusion.

Based on the tight connection between FMN release and IRI, both starting from the same pocket in complex I, FMN release could also be a useful marker for viability during other perfusion approaches. Wang et al. have now demonstrated the impact of FMN as a biomarker during normothermic kidney perfusion and normothermic regional perfusion (NRP) in DCD donors [102]. Perfusate FMN predicted posttransplant renal function and the FMN value at 30 min of NRP may support clinicians to accept DCD donors or not [102].

During ischemia the electron transport across mitochondrial complexes is impaired and next to succinate, another molecule, NADH accumulates. The metabolic reaction of $\mathrm{NADH}$ to donate protons for the $\mathrm{H}+$ gradient and electrons, both for the ATP production is linked within the same area in complex I. An improved complex I function through HOPE treatment, leads therefore to increased NADH metabolization. Similarly, to FMN, the molecule NADH has autofluorescence abilities and is used for viability assessment. Already in 2013, the link between perfusate NADH concentration and mitochondrial metabolism 
was demonstrated [103]. Confirmed through mass spectrometry analysis, the threshold of 10,000 A.U. perfusate NADH was established at $30 \mathrm{~min}$ of HOPE and is routinely used in combination with FMN cut-offs to provide a more accurate assessment of mitochondrial complex I function and injury (Table 2, Figure 5) [38]. As with all used markers for viability, NADH was described earlier. Van Golen et al. have shown the importance of the autofluorescence abilities to determine viability as a surrogate for mitochondrial function and cellular energy [32]. Several multicentric clinical and experimental studies are currently ongoing with different perfusion techniques to further validate both complex I markers. The FMN pocket in complex I (NDUFS-1) was recently immuno-stained. Interestingly, a fully functional mitochondria complex I appears colored, while in liver cells with advanced complex I injury the NDUFS-1 unit is released into the cytosol [38].

\section{Summary and Future Perspective}

Multiple parameters to assess viability during machine perfusion have been suggested within the last 5 years. Today there is no widely accepted marker, which is reliable to provide enough confidence to accept a liver [52]. Two potential strategies are available. The identification of multiple parameters with complicated assessment, requiring computerized artificial intelligence to decide if to accept an organ. Or a simple key parameter, which is linked to the central mechanism of organ injury initiated in the mitochondria. A few steps are crucial to improve the current situation: first, the general agreement to store perfusate and tissue from any machine perfused liver in a local or central biobank. The collection of larger sample sizes allows to merge samples and to perform a systematic screening for biomarkers. Next, results from expected randomized controlled trials including livers with higher risk will hopefully reduce the differences among perfusion protocols, which include perfusate composition, perfusion route, duration, device used, supplements etc. This is very important to achieve more specific and generalized data. Third, technical advances will help to obtain results from miRNA detection, ATP quantification, and metabolic profiling within shorter time. Above all, collaborative approaches are needed to merge the cases, perfusion samples, and ideas to identify one marker, which is quick, cheap, and ideally assessable in real-time during perfusion with all devices and at all temperatures.

Author Contributions: Conceptualization, R.P., M.F.C., and A.S.; resources A.S.; data curation R.P., D.M. and A.S.; writing-original draft preparation R.P., M.F.C., and A.S.; writing-review and editing, M.M., P.D., P.M., and A.S.; visualization, M.F.C. and A.S.; supervision: A.S. All authors have read and agreed to the published version of the manuscript.

Funding: P.D. and A.S. are supported by the Swiss National Science Foundation grant no 320030_189055. P.M. and A.S. are further supported by the University of Florence through grant $n^{\circ} 90-2020 / P R$. This work was further supported by the Max Planck Society dedicated to D.M.

Institutional Review Board Statement: Not applicable.

Informed Consent Statement: Not applicable.

Data Availability Statement: Not applicable.

Acknowledgments: The authors acknowledge the kind support by the funding agencies mentioned above.

Conflicts of Interest: The authors declare no conflict of interest. The funders had no role in the design of the review; in the interpretation of literature; in the writing of the manuscript, or in the decision regarding publication.

\section{References}

1. Schlegel, A.; Muller, X.; Dutkowski, P. Hypothermic Liver Perfusion. Curr. Opin. Organ. Transpl. 2017, 22, 563-570. [CrossRef] [PubMed]

2. Boteon, Y.; Afford, S.; Mergental, H. Pushing the Limits: Machine Preservation of the Liver as a Tool to Recondition High-Risk Grafts. Curr. Transpl. Rep. 2018, 5, 113-120. [CrossRef]

3. Lindbergh, C.A. An apparatus for the culture of whole organs. J. Exp. Med. 1935, 62, 409. [CrossRef] [PubMed] 
4. Friend, P.J. Strategies in Organ Preservation-A New Golden Age. Transplantation 2020, 104, 1753-1755. [CrossRef] [PubMed]

5. Sutherland, A.; Oniscu, G. Challenges and advances in optimizing liver allografts from donation after circulatory death donors. J. Nat. Sci. Biol. Med. 2016, 7, 10-15. [CrossRef] [PubMed]

6. Ceresa, C.D.L.; Nasralla, D.; Jassem, W. Normothermic Machine Preservation of the Liver: State of the Art. Curr. Transpl. Rep. 2018. [CrossRef]

7. He, X.; Guo, Z.; Zhao, Q.; Ju, W.; Wang, D.; Wu, L.; Yang, L.; Ji, F.; Tang, Y.; Zhang, Z.; et al. The first case of ischemia-free organ transplantation in humans: A proof of concept. Am. J. Transpl. 2018, 18, 737-744. [CrossRef] [PubMed]

8. Graham, J.A.; Guarrera, J.V. "resuscitation" of marginal liver allografts for transplantation with machine perfusion technology. J. Hepatol. 2014, 61, 418-431. [CrossRef]

9. Mergental, H.; Laing, R.W.; Kirkham, A.J.; Perera, M.T.P.R.; Boteon, Y.L.; Attard, J.; Barton, D.; Curbishley, S.; Wilkhu, M.; Neil, D.A.H.; et al. Transplantation of discarded livers following viability testing with normothermic machine perfusion. Nat. Commun. 2020, 11, 1-12. [CrossRef]

10. Nasralla, D.; Coussios, C.C.; Mergental, H.; Akhtar, M.Z.; Butler, A.J.; Ceresa, C.D.L.; Chiocchia, V.; Dutton, S.J.; Garcia-Valdecasas, J.C.; Heaton, N.; et al. A randomized trial of normothermic preservation in liver transplantation. Nature 2018, 557, 50-56. [CrossRef] [PubMed]

11. Van Rijn, R.; Van Den Berg, A.P.; Erdmann, J.I.; Heaton, N.; Van Hoek, B.; De Jonge, J. Study protocol for a multicenter randomized controlled trial to compare the efficacy of end-ischemic dual hypothermic oxygenated machine perfusion with static cold storage in preventing non-anastomotic biliary strictures after transplantation of liver gra. BMC Gastroenterol. 2019. [CrossRef]

12. Eshmuminov, D.; Becker, D.; Bautista Borrego, L.; Hefti, M.; Schuler, M.J.; Hagedorn, C.; Muller, X.; Mueller, M.; Onder, C.; Graf, R.; et al. An integrated perfusion machine preserves injured human livers for 1 week. Nat. Biotechnol. 2020, 38, 189-198. [CrossRef] [PubMed]

13. Ciria, R.; Ayllon-Teran, M.D.; González-Rubio, S.; Gómez-Luque, I.; Ferrín, G.; Moreno, A.; Sanchez-Frias, M.; Alconchel, F.; Herrera, C.; Martin, V.; et al. Rescue of Discarded Grafts for Liver Transplantation by Ex Vivo Subnormothermic and Normothermic Oxygenated Machine Perfusion: First Experience in Spain. Transpl. Proc. 2019, 51, 20-24. [CrossRef]

14. Mergental, H.; Stephenson, B.T.F.; Laing, R.W.; Kirkham, A.J.; Neil, D.A.H.; Wallace, L.L.; Boteon Yuri, L.; Widmer, J.e.a.n.n.e.t.t.e.; Bhogal Ricky, H.; Perera MThamara, P.R.; et al. Development of Clinical Criteria for Functional Assessment to Predict Primary Nonfunction of High-Risk Livers Using Normothermic Machine Perfusion. Liver Transpl. 2018, 24, 1453-1469. [CrossRef] [PubMed]

15. Linares-Cervantes, I.; Echeverri, J.; Cleland, S.; Kaths, J.M.; Rosales, R.; Goto, T.; Kollmann, D.; Hamar, M.; Urbanellis, P.; Mazilescu, L.; et al. Predictor parameters of liver viability during porcine normothermic ex situ liver perfusion in a model of liver transplantation with marginal grafts. Am. J. Transpl. 2019, 19, 2991-3005. [CrossRef] [PubMed]

16. Sutton, M.E.; Op Den Dries, S.; Karimian, N.; Weeder, P.D.; De Boer, M.T.; Wiersema-Buist, J.; Gouw, A.S.H.; Leuvenink, H.G.D.; Lisman, T.; Porte, R.J. Criteria for Viability Assessment of Discarded Human Donor Livers during Ex Vivo Normothermic Machine Perfusion. PLoS ONE 2014, 9, e0110642. [CrossRef]

17. Raigani, S.; De Vries, R.J.; Carroll, C.; Chen, Y.W.; Chang, D.C.; Shroff, S.G.; Uygun, K.; Yeh, H. Viability testing of discarded livers with normothermic machine perfusion: Alleviating the organ shortage outweighs the cost. Clin. Transpl. 2020, 34, e14069. [CrossRef] [PubMed]

18. Patrono, D.; Catalano, G.; Rizza, G.; Lavorato, N.; Berchialla, P.; Gambella, A.; Caropreso, P.; Mengozzi, G.; Romagnoli, R. Perfusate Analysis during Dual Hypothermic Oxygenated Machine Perfusion of Liver Grafts: Correlations with Donor Factors and Early Outcomes. Transplantation 2020, 104, 1929-1942. [CrossRef]

19. Matton, A.P.M.; de Vries, Y.; Burlage, L.C.; van Rijn, R.; Fujiyoshi, M.; de Meijer, V.E.; de Boer, M.T.; de Kleine, R.H.J.; Verkade, H.J.; Gouw, A.S.H.; et al. Biliary Bicarbonate, pH, and Glucose Are Suitable Biomarkers of Biliary Viability During Ex Situ Normothermic Machine Perfusion of Human Donor Livers. Transplantation 2019, 103, 1405. [CrossRef]

20. de Vries, Y.; Matton, A.; Nijsten, M.; Werner, M.; van den Berg, A.; de Boer, M.; Buis, C.I.; Fujiyoshi, M.; de Kleine, R.H.J.; van Leeuwen, O.B.; et al. Pretransplant Sequential Hypo- and Normothermic Machine Perfusion of Suboptimal Livers Donated after Circulatory Death Using a Hemoglobin-based Oxygen Carrier Perfusion Solution. Am. J. Transpl. 2018, 19, 1202-1211. [CrossRef]

21. Ceresa, C.D.L.; Nasralla, D.; Watson, C.J.E.; Butler, A.J.; Coussios, C.C.; Crick, K.; Hodson, L.; Imber, C.; Jassem, W.; Knight, S.R.; et al. Transient Cold Storage Prior to Normothermic Liver Perfusion May Facilitate Adoption of a Novel Technology. Liver Transpl. 2019. [CrossRef]

22. Bral, M.; Gala-Lopez, B.; Bigam, D.; Kneteman, N.; Malcolm, A.; Livingstone, S.; Andres, A.; Emamaullee, J.; Russell, L.; Coussios, C.; et al. Preliminary Single-Center Canadian Experience of Human Normothermic Ex Vivo Liver Perfusion: Results of a Clinical Trial. Am. J. Transpl. 2017, 17, 1071-1080. [CrossRef]

23. Muller, X.; Schlegel, A.; Kron, P.; Eshmuminov, D.; Würdinger, M.; Meierhofer, D.; Clavien, P.; Dutkowski, P. Novel real time prediction of liver graft function during hypothermic oxygenated machine perfusion prior to liver transplantation. Ann. Surg. 2019, 270, 783-790. [CrossRef] [PubMed]

24. Moldenhauer, J. Use of a viability test method: Does it mean what you think? Am. Pharm. Rev. 2010, 13, 22.

25. Attard, J.A.; Dunn, W.B.; Mergental, H.; Mirza, D.F.; Afford, S.C.; Perera, M.T.P.R. Systematic Review: Clinical Metabolomics to Forecast Outcomes in Liver Transplantation Surgery. Omi. A J. Integr. Biol. 2019, 23, 463-476. [CrossRef] 
26. Marcon, F.; Schlegel, A.; Bartlett, D.; Bishop, D.; Mergental, H.; Roberts, K.; Mirza, D.F.; Isaac, J.; Muiesan, P. Utilisation of declined liver grafts yields comparable transplant outcomes and previous decline should not be a deterrent to graft use. Transplantation 2018, 102, e211-e218. [CrossRef]

27. Goldberg, D.S.; French, B.; Lewis, J.D.; Scott, F.I.; Mamtani, R.; Gilroy, R.; Halpern, S.D.; Abt, P.L. Liver transplant center variability in accepting organ offers and its impact on patient survival. J. Hepatol. 2016, 64, 843-851. [CrossRef]

28. Schlegel, A.; Scalera, I.; Perera, M.T.P.R.; Kalisvaart, M.; Mergental, H.; Mirza, D.F.; Isaac, J.; Muiesan, P. Impact of donor age in donation after circulatory death liver transplantation: Is the cutoff "60" still of relevance? Liver Transpl. 2018, 24, 352-362. [CrossRef] [PubMed]

29. Croome, K.P.; Lee, D.D.; Keaveny, A.P.; Burcin Taner, C. Improving National Results in Liver Transplantation Using Grafts from Donation after Cardiac Death Donors. Transplantation 2016, 100, 2640-2647. [CrossRef]

30. Kalisvaart, M.; Muiesan, P.; Schlegel, A. The UK-DCD-Risk-Score-practical and new guidance for allocation of a specific organ to a recipient? Expert Rev. Gastroenterol. Hepatol. 2019, 13, 771-783. [CrossRef] [PubMed]

31. De Vries, Y.; Berendsen, T.A.; Fujiyoshi, M.; Van Den Berg, A.P.; Blokzijl, H.; De Boer, M.T. Transplantation of high-risk donor livers after resuscitation and viability assessment using a combined protocol of oxygenated hypothermic, rewarming and normothermic machine perfusion: Study protocol for a prospective, single-arm study (DHOPE-COR-NMP tri. BMJ Open 2019, 9, e028596. [CrossRef] [PubMed]

32. Van Golen, R.F.; Van Gulik, T.M.; Heger, M. Mechanistic overview of reactive species-induced degradation of the endothelial glycocalyx during hepatic ischemia/reperfusion injury. Free Radic. Biol. Med. 2012, 52, 1382-1402. [CrossRef] [PubMed]

33. Land, W.G. Emerging role of innate immunity in organ transplantation. Part I: Evolution of innate immunity and oxidative allograft injury. Transpl. Rev. 2012, 26, 60-72. [CrossRef]

34. Chouchani, E.T.; Pell, V.R.; James, A.M.; Work, L.M.; Saeb-Parsy, K.; Frezza, C.; Krieg, T.; Murphy, M.P. A unifying mechanism for mitochondrial superoxide production during ischemia-reperfusion injury. Cell Metab. 2016, 23, 254-263. [CrossRef]

35. Hofmann, J.; Otarashvili, G.; Meszaros, A.; Ebner, S.; Weissenbacher, A.; Cardini, B.; Oberhuber, R.; Resch, T.; Ofner, D.; Schneeberger, S.; et al. Restoring mitochondrial function while avoiding redox stress: The key to preventing ischemia/reperfusion injury in machine perfused liver grafts? Int. J. Mol. Sci. 2020, 21, 3132. [CrossRef]

36. Mills, E.L.; Kelly, B.; O'neill, L.A.J. Mitochondria are the powerhouses of immunity. Nat. Immunol. 2017, 18, 488-498. [CrossRef] [PubMed]

37. Stegemann, J.; Minor, T. Energy charge restoration, mitochondrial protection and reversal of preservation induced liver injury by hypothermic oxygenation prior to reperfusion. Cryobiology 2009, 58, 331-336. [CrossRef]

38. Schlegel, A.; Muller, X.; Mueller, M.; Stepanova, A.; Kron, P.; de Rougemont, O.; Muiesan, P.; Clavien, P.; Galkin, A.; Meierhofer, D.; et al. Hypothermic oxygenated perfusion protects from mitochondrial injury before liver transplantation. EBioMedicine 2020, 60, 103014. [CrossRef] [PubMed]

39. Westerkamp, A.; Karimian, N.; Matton, A.; Mahboub, P.; van Rijn, R.; Wiersema-Buist, J.; de Boer, M.T.; Leuvenink, H.G.D.; Gouw, A.S.H.; Lisman, T.; et al. Oxygenated Hypothermic Machine Perfusion After Static Cold Storage Improves Hepatobiliary Function of Extended Criteria Donor Livers. Transplantation 2016, 100, 825-835. [CrossRef]

40. Murphy, M.P. How mitochondria produce reactive oxygen species. Biochem. J. 2009, 417, 1-13. [CrossRef] [PubMed]

41. Chouchani, E.T.; Pell, V.R.; Gaude, E.; Aksentijević, D.; Sundier, S.Y.; Robb, E.L.; Logan, A.; Nadtochiy, S.M.; Ord, E.N.J.; Smith, A.C.; et al. Ischaemic accumulation of succinate controls reperfusion injury through mitochondrial ROS. Nature 2014, 515, 431-435. [CrossRef]

42. Granger, D.N.; Kvietys, P.R. Reperfusion injury and reactive oxygen species: The evolution of a concept. Redox Biol. 2015, 6, 524-551. [CrossRef]

43. Kron, P.; Schlegel, A.; Mancina, L.; Clavien, P.A.; Dutkowski, P. Hypothermic oxygenated perfusion (HOPE) for fatty liver grafts in rats and humans. J. Hepatol. 2018, 68, 82-91. [CrossRef]

44. Kim, M.; Stepanova, A.; Niatsetskaya, Z.; Sosunov, S.; Arndt, S.; Murphy, M.P.; Galkin, A.; Ten, V.S. Attenuation of oxidative damage by targeting mitochondrial complex I in neonatal hypoxic-ischemic brain injury. Free Radic. Biol. Med. 2018. [CrossRef]

45. Mills, E.L.; Kelly, B.; Logan, A.; Costa, A.S.H.; Varma, M.; Bryant, C.E.; Tourlomousis, P.; Dabritz, J.H.M.; Gottlieb, E.; Latorre, I.; et al. Succinate Dehydrogenase Supports Metabolic Repurposing of Mitochondria to Drive Inflammatory Macrophages. Cell 2016, 167, 457-470. [CrossRef] [PubMed]

46. Kim, J.S.; Boudjema, K.; D'Alessandro, A.; Southard, J.H. Machine perfusion of the liver: Maintenance of mitochondrial function after 48-h preservation. Transpl. Proc. 1997, 29, 3452-3454. [CrossRef]

47. Westerkamp, A.C.; Mahboub, P.; Meyer, S.L.; Hottenrott, M.; Ottens, P.J.; Wiersema-Buist, J.; Gouw, A.S.H.; Lisman, T.; Leuvenink, H.G.D.; Porte, R.J. End-ischemic machine perfusion reduces bile duct injury in donation after circulatory death rat donor livers independent of the machine perfusion temperature. Liver Transpl. 2015, 21, 1300-1311. [CrossRef]

48. Van Rijn, R.; Karimian, N.; Matton, A.; Burlage, L.; Wetserkamp, A.; van den Berg, A.; de Kleine, R.H.J.; de Boer, M.T.; Lisman, T.; Porte, R.J. Dual hypothermic oxygenated machine perfusion in liver transplants donated after circulatory death. Br. J. Surg. 2017, 104, 907-917. [CrossRef] [PubMed]

49. Todd, J.L.; Palmer, S.M. Danger signals in regulating the immune response to solid organ transplantation. J. Clin. Investig. 2017, 127, 2464-2472. [CrossRef] [PubMed] 
50. Schlegel, A.; Kron, P.; Graf, R.; Dutkowski, P.; Clavien, P.A. Warm vs. cold perfusion techniques to rescue rodent liver grafts. J. Hepatol. 2014, 61, 1267-1275. [CrossRef]

51. Longatto Boteon, Y.; Schlegel, A.; Laing, R.; Attard, J.; Bhogal, R.; Wallace, L.; Reynolds, G.; Mirza, D.; Mergental, H.; Afford, $\mathrm{S}$. Combination of hypothermic oxygenated machine perfusion followed by normothermic machine perfusion optimises the reconditioning of marginal human donor livers. HPB 2018, 20, S823. [CrossRef]

52. Brüggenwirth, I.M.A.; de Meijer, V.E.; Porte, R.J.; Martins, P.N. Viability criteria assessment during liver machine perfusion. Nat. Biotechnol. 2020, 38, 1260-1262. [CrossRef] [PubMed]

53. Dröse, S.; Brandt, U.; Wittig, I. Mitochondrial respiratory chain complexes as sources and targets of thiol-based redox-regulation. Biochim. Biophys. Acta Proteins Proteomics 2014, 1844, 1344-1354. [CrossRef] [PubMed]

54. Stepanova, A.; Kahl, A.; Konrad, C.; Ten, V.; Starkov, A.S.; Galkin, A. Reverse electron transfer results in a loss of flavin from mitochondrial complex I: Potential mechanism for brain ischemia reperfusion injury. J. Cereb. Blood Flow Metab. 2017, 37, 3649-3658. [CrossRef]

55. Iwasaki, M.; Takada, Y.; Hayashi, M.; Minamiguchi, S.; Haga, H.; Maetani, Y.; Fujii, K.; Kiuchi, T.; Tanaka, K. Noninvasive evaluation of graft steatosis in living donor liver transplantation. Transplantation 2004, 78, 1501-1505. [CrossRef]

56. El-Badry, A.M.; Breitenstein, S.; Jochum, W.; Washington, K.; Paradis, V.; Rubbia-Brandt, L.; Puhan, M.A.; Slankamenac, K.; Graf, R.; Clavien, P. Assessment of hepatic steatosis by expert pathologists: The end of a gold standard. Ann. Surg. 2009, 250, 691-697. [CrossRef] [PubMed]

57. Ravikumar, R.; Jassem, W.; Mergental, H.; Heaton, N.; Mirza, D.; Perera, M.T.P.R.; Quaglia, A.; Holroyd, D.; Vogel, T.; Coussios, C.C.; et al. Liver Transplantation After Ex Vivo Normothermic Machine Preservation: A Phase 1 (First-in-Man) Clinical Trial. Am. J. Transpl. 2016, 16, 1779-1787. [CrossRef] [PubMed]

58. Watson, C.J.E.; Kosmoliaptsis, V.; Randle, L.V.; Gimson, A.E.; Brais, R.; Klinck, J.R.; Hamed, M.; Tsyben, A.; Butler, A.J. Normothermic perfusion in the assessment and preservation of declined livers before transplantation: Hyperoxia and vasoplegiaimportant lessons from the first 12 cases. Transplantation 2017, 101, 1084. [CrossRef] [PubMed]

59. Reiling, J.; Butler, N.; Simpson, A.; Hodgkinson, P.; Campbell, C.; Lockwood, D.; Bridle, K.; Santrampurwala, N.; Britton, L.; Crawford, D.; et al. Assessment and Transplantation of Orphan Donor Livers: A Back-to-Base Approach to Normothermic Machine Perfusion. Liver Transpl. 2020, 26, 1618-1628. [CrossRef]

60. Watson, C.; Kosmoliaptsis, V.; Pley, C.; Randle, L.; Fear, C.; Crick, K.; Gimson, A.E.; Allison, M.; Upponi, S.; Brais, R.; et al. Observations on the ex situ perfusion of livers for transplantation. Am. J. Transpl. 2018, 18, 2005-2020. [CrossRef]

61. Matton, A.P.M.; Selten, J.W.; Roest, H.P.; de Jonge, J.; IJzermans, J.N.M.; de Meijer, V.E.; Porte, R.J.; van der Laan, L.J.W. Cell-free microRNAs as early predictors of graft viability during ex vivo normothermic machine perfusion of human donor livers. Clin. Transpl. 2020, 34, e13790. [CrossRef] [PubMed]

62. Zhang, Q.; Raoof, M.; Chen, Y.; Sumi, Y.; Sursal, T.; Junger, W.; Brohi, K.; Itagaki, K.; Hauser, C.J. Circulating mitochondrial DAMPs cause inflammatory responses to injury. Nature 2010, 464, 104-107. [CrossRef]

63. Jara, M.; Malinowski, M.; Lüttgert, K.; Schott, E.; Neuhaus, P.; Stockmann, M. Prognostic value of enzymatic liver function for the estimation of short-term survival of liver transplant candidates: A prospective study with the LiMAx test. Transpl. Int. 2015, 28, 52-58. [CrossRef]

64. Dutkowski, P.; Mueller, M.; Eshmuminov, D.; Bautista Borrego, L.; Becker, D.; Hefti, M.; Schuler, M.J.; von Rohr, P.R.; Clavien, P. Reply to: Lactate measurements in an integrated perfusion machine for human livers. Nat. Biotechnol. 2020, 38, 1263-1264. [CrossRef] [PubMed]

65. Guarrera, J.V.; Henry, S.D.; Chen, S.W.C.; Brown, T.; Nachber, E.; Arrington, B.; Boykin, J.; Samstein, B.; Brown, R.S., Jr.; Emond, J.C.; et al. Hypothermic machine preservation attenuates ischemia/reperfusion markers after liver transplantation: Preliminary results. J. Surg. Res. 2011, 167, e365-e373. [CrossRef] [PubMed]

66. Okaya, T.; Blanchard, J.; Schuster, R.; Kuboki, S.; Husted, T.; Caldwell, C.C.; Zingarelli, B.; Wong, H.; Solomkin, J.S.; Lentsch, A.B. Age-dependent responses to hepatic ischemia/reperfusion injury. Shock 2005, 24, 421-427. [CrossRef]

67. Hosgood, S.A.; Patel, M.; Nicholson, M.L. The conditioning effect of ex vivo normothermic perfusion in an experimental kidney model. J. Surg. Res. 2013, 182, 153-160. [CrossRef]

68. Thirunavayakalathil, M.; Varghese, C.; Bharathan, V.; Chandran, B.; Nair, K.; Mallick, S.; Mathew, J.S.; Amma, B.S.P.T.; Menon, R.N.; Gopalakrishnan, U.; et al. Double-blind placebo-controlled randomized trial of N-acetylcysteine infusion following live donor liver transplantation. Hepatol. Int. 2020, 1-8. [CrossRef]

69. Lindell, S.L.; Klahn, S.L.; Piazza, T.M.; Mangino, M.J.; Torrealba, J.R.; Southard, J.H.; Carey, H.V. Natural resistance to liver cold ischemia-reperfusion injury associated with the hibernation phenotype. Am. J. Physiol. Gastrointest Liver Physiol. 2005, 288, G473-G480. [CrossRef]

70. Jani, A.; Epperson, E.; Martin, J.; Pacic, A.; Ljubanovic, D.; Martin, S.L.; Edelstein, C.L. Renal protection from prolonged cold ischemia and warm reperfusion in hibernating squirrels. Transplantation 2011, 92, 1215-1221. [CrossRef]

71. Abele, D. Toxic oxygen: The radical life-giver. Nature 2002, 420, 27. [CrossRef]

72. Sumimoto, K.; Inagaki, K.; Yamada, K.; Kawasaki, T.; Dohi, K. Reliable indices for the determination of viability of grafted liver immediately after orthotopic transplantation: Bile flow rate and cellular adenosine triphosphate level. Transplantation 1988, 46, 506-509. [CrossRef] [PubMed] 
73. Boteon, Y.L.; Afford, S.C. Machine perfusion of the liver: Which is the best technique to mitigate ischaemia-reperfusion injury? World J. Transpl. 2019. [CrossRef]

74. Zhang, Z.; Ju, A.W.; Tang, Y.; Wang, L.; Zhu, C.; Gao, N.; Zhao, Q.; Huang, S.; Wang, D.; Yang, L.; et al. First preliminary experience with preservation of liver grafts from extended-criteria donors by normothermic machine perfusion in Asia. Ann. Transpl. 2020, 25, e921529. [CrossRef]

75. Monbaliu, D.; Liu, Q.; Libbrecht, L.; De Vos, R.; Vekemans, K.; Debbaut, C.; Detry, O.; Roskams, T.; van Pelt, J.; Pirenne, J. Preserving the morphology and evaluating the quality of liver grafts by hypothermic machine perfusion: A proof-of-concept study using discarded human livers. Liver Transpl. 2012, 18, 1495-1507. [CrossRef]

76. Fukumori, T.; Ohkohchi, N.; Tsukamoto, S.; Satomi, S. Why is fatty liver unsuitable for transplantation? Deterioration of mitochondrial ATP synthesis and sinusoidal structure during cold preservation of a liver with steatosis. Transpl. Proc. 1997, 29, 412-415. [CrossRef]

77. Laing, R.W.; Scalera, I.; Isaac, J.; Mergental, H.; Mirza, D.F.; Hodson, J.; Wilkin, R.J.W.; Perera, M.T.P.R.; Muiesan, P. Liver transplantation using grafts from donors after circulatory death: A propensity-matched study from a single centre. Am. J. Transpl. 2016, 16, 1795-1804. [CrossRef]

78. Cardini, B.; Oberhuber, R.; Fodor, M.; Hautz, T.; Margreiter, C.; Resch, T.; Scheidl, S.; Maglione, M.; Bosmuller, C.; Mair, H.; et al. Clinical Implementation of Prolonged Liver Preservation and Monitoring through Normothermic Machine Perfusion in Liver Transplantation. Transplantation 2020, 104, 1917-1928. [CrossRef] [PubMed]

79. Dutkowski, P.; Southard, J.H.; Junginger, T. Liver metabolism during cold ischemic incubation in UW solution in the rat model. Langenbecks Arch. Chir. 1997, 382, 343-348. [PubMed]

80. Mergental, H.; Perera, M.T.P.R.; Laing, R.W.; Muiesan, P.; Isaac, J.R.; Smith, A.; Stephenson, B.T.F.; Cilliers, H.; Neil, D.A.H.; Hubscher, S.G.; et al. Transplantation of Declined Liver Allografts Following Normothermic Ex-Situ Evaluation. Am. J. Transpl. 2016, 16, 3235-3245. [CrossRef]

81. Van Leeuwen, O.B.; De Vries, Y.; Fujiyoshi, M.; Nijsten, M.W.N.; Ubbink, R.; Pelgrim, G.J.; Werner, M.J.M.; Reyntjens, K.M.E.M.; van den Berg, A.P.; de Boer, M.T.; et al. Transplantation of high-risk donor livers after ex situ resuscitation and assessment using combined hypo- A nd normothermic machine perfusion: A prospective clinical trial. Ann. Surg. 2019. [CrossRef]

82. Schroeder, T.H.; Hansen, M. Effects of fresh versus old stored blood in the priming solution on whole blood lactate levels during paediatric cardiac surgery. Perfusion 2005, 20, 17-19. [CrossRef] [PubMed]

83. Op Den Dries, S.; Sutton, M.E.; Lisman, T.; Porte, R.J. Protection of bile ducts in liver transplantation: Looking beyond ischemia. Transplantation 2011, 92, 373-379. [CrossRef]

84. Tabibian, J.H.; Masyuk, A.I.; Masyuk, T.V.; O’hara, S.P.; LaRusso, N.F. Physiology of cholangiocytes. Compr. Physiol. 2013, 3, 541-565. [CrossRef]

85. Guzelian, P.; Boyer, J.L. Glucose reabsorption from bile. Evidence for a biliohepatic circulation. J. Clin. Investig. 1974, 53, 526-535. [CrossRef]

86. Meurisse, N.; Vanden Bussche, S.; Jochmans, I.; Francois, J.; Desschans, B.; Laleman, W.; Van der Merwe, S.; van Steenbergen, W.; Cassiman, D.; Verslype, C.; et al. Outcomes of liver transplantations using donations after circulatory death: A single-center experience. Transpl. Proc. 2012, 44, 2868-2873. [CrossRef] [PubMed]

87. DeOliveira, M.L.; Jassem, W.; Valente, R.; Khorsandi, S.E.; Santori, G.; Prachalias, A.; Srinivasan, P.; Rela, M.; Heaton, N. Biliary complications after liver transplantation using grafts from donors after cardiac death: Results from a matched control study in a single large volume center. Ann. Surg. 2011, 254, 716-722. [CrossRef]

88. Kollmann, D.; Sapisochin, G.; Goldaracena, N.; Hansen, B.E.; Rajakumar, R.; Selzner, N.; Bhat, M.; McCluskey, S.; Cattral, M.S.; Greig, P.D.; et al. Expanding the donor pool: Donation after circulatory death and living liver donation do not compromise the results of liver transplantation. Liver Transpl. 2018, 24, 779-789. [CrossRef] [PubMed]

89. Karangwa, S.; Panayotova, G.; Dutkowski, P.; Porte, R.J.; Guarrera, J.V.; Schlegel, A. Hypothermic Machine Perfusion in Liver Transplantation. Int. J. Surg. 2020, 82, 44-51. [CrossRef] [PubMed]

90. Henry, S.D.; Nachber, E.; Tulipan, J.; Stone, J.; Bae, C.; Reznik, L.; Kato, T.; Samstein, B.; Emond, J.C.; Guarrera, J.V. Hypothermic machine preservation reduces molecular markers of ischemia/reperfusion injury in human liver transplantation. Am. J. Transpl. 2012. [CrossRef]

91. Tulipan, J.E.; Stone, J.; Samstein, B.; Kato, T.; Emond, J.C.; Henry, S.D.; Guarrera, J.V. Molecular expression of acute phase mediators is attenuated by machine preservation in human liver transplantation: Preliminary analysis of effluent, serum, and liver biopsies. Surgery 2011, 150, 352-360. [CrossRef] [PubMed]

92. Schlegel, A.; Kron, P.; De Oliveira, M.L.; Clavien, P.A.; Dutkowski, P. Reply to "Is single portal vein perfusion the best approach for machine preservation of liver grafts?". J. Hepatol. 2016, 64, 1195-1196. [CrossRef]

93. Schlegel, A.; Kron, P.; De Oliveira, M.L.; Clavien, P.A.; Dutkowski, P. Is single portal vein approach sufficient for hypothermic machine perfusion of DCD liver grafts? J. Hepatol. 2016, 64, 239-241. [CrossRef]

94. Mitchell, S.J.; Churchill, T.A.; Winslet, M.C.; Fuller, B.J. Effects of different cold preservation solutions on restoration of hepatic energy metabolism during cold reperfusion. Cryobiology 1996, 33, 413-422. [CrossRef]

95. Dutkowski, P.; Furrer, K.; Tian, Y.; Graf, R.; Clavien, P.-A. Novel short-term hypothermic oxygenated perfusion (HOPE) system prevents injury in rat liver graft from non-heart beating donor. Ann. Surg. 2006, 244, 968-976. [CrossRef] 
96. Jain, S.; Lee, S.H.; Korneszczuk, K.; Culberson, C.R.; Southard, J.H.; Berthiaume, F.; Zhang, J.X.; Clemens, M.G.; Lee, C.Y. Improved preservation of warm ischemic livers by hypothermic machine perfusion with supplemented University of Wisconsin solution. J. Investig. Surg. 2008, 21, 83-91. [CrossRef] [PubMed]

97. Kahl, A.; Stepanova, A.; Konrad, C.; Anderson, C.; Manfredi, G.; Zhou, P.; Iadecola, C.; Galkin, A. Critical Role of Flavin and Glutathione in Complex I-Mediated Bioenergetic Failure in Brain Ischemia/Reperfusion Injury. Stroke 2018, 49, 1223-1231. [CrossRef]

98. Stepanova, A.; Sosunov, S.; Niatsetskaya, Z.; Konrad, C.; Starkov, A.; Manfredi, G.; Wittig, I.; Ten, V.; Galkin, A. Redox-Dependent Loss of Flavin by Mitochondrial Complex I in Brain Ischemia/Reperfusion Injury. Antioxid. Redox Signal. 2019, 31, 608-622. [CrossRef]

99. Holt, P.J.; Efremov, R.G.; Nakamaru-Ogiso, E.; Sazanov, L.A. Reversible FMN dissociation from Escherichia coli respiratory complex I. Biochim. Biophys. Acta Bioenerg. 2016, 1857, 1777-1785. [CrossRef] [PubMed]

100. Scholz, R.; Thurman, R.G.; Williamson, J.R.; Chance, B.; Bücher, T. Flavin and pyridine nucleotide oxidation-reduction changes in perfused rat liver. I. Anoxia and subcellular localization of fluorescent flavoproteins. J. Biol. Chem. 1969, 244, $2317-2324$. [CrossRef]

101. Panayotova, G.; Cutler, Q.; Paterno, F.; McCarty, M.; Bailey, A.; Dikdan, G.; Rosado, J.; Schlegel, A.; Dutkowski, P.; Shah, S.; et al. A Novel Biomarker to Predict Ischemia/Reperfusion Injury after Hypothermic Oxygenated Machine Preservation in Human Liver Transplants. ASTS 2019, 20, 78.

102. Wang, L.; Thompson, E.; Bates, L.; Pither, T.L.; Hosgood, S.A.; Nicholson, M.L.; Watson, C.J.E.; Wilson, C.; Fisher, A.J.; Ali, S.; et al. Flavin mononucleotide as a biomarker of organ quality-A pilot study. Transpl. Direct 2020, 6. [CrossRef]

103. Schlegel, A.; Rougemont, O.D.E.; Graf, R.; Clavien, P.A.; Dutkowski, P. Protective mechanisms of end-ischemic cold machine perfusion in DCD liver grafts. J. Hepatol. 2013, 58, 278-286. [CrossRef] [PubMed] 